\title{
The Effect of Capital Structure Gearing Levels on Financial Performance of Public and Private Sector Firms in Kenya's Coastal Counties
}

\author{
Swalhah Ibrahim Yusuf ${ }^{1}$, Samuel M. Mwakubo ${ }^{1} \&$ Ali Ibrahim Abdallah ${ }^{1}$ \\ ${ }^{1}$ Department of Business Management and Economics, School of Business and Economics, Pwani University, \\ Kenya \\ Correspondence: Swalhah Ibrahim Yusuf, Department of Business Management and Economics, School of \\ Business and Economics, Pwani University, Kenya. E-mail: swaz.ibra48@ gmail.com
}

Received: November 16, 2018

Accepted: February 25, 2019 Online Published: February 28, 2019

doi:10.5539/ijef.v11n3p99

URL: https://doi.org/10.5539/ijef.v11n3p99

\begin{abstract}
Many firms were set up in Kenya to produce goods and services for consumption in Kenya and beyond. Some were set up in Kenya's coastal counties after independence. As at June 1990 however, most them had either collapsed, liquidated, were ailing and few were performing fairly. By 2015, there were 194 public firms which were in operations and most of them had poor financial performance as measured by accounting and market ratios (ROE and ROA). In the small enterprise segment, about 300,000 SME's were set up in 2010 to 2012. About $96 \%$ of them had closed down by the end of their first year in operations. The questions were 'why did firms underperform and why did these firms fail?'. Published annual financial reports of firms attributed the poor financial performance and failure to many factors; high cost of energy, intense competition, high cost of raw materials, obsolete equipment, poor management, poor technical skills, high cost of finance and other bank charges, inadequate finance, family feuds, lack of succession plan etc. Some studies attributed poor financial performance and failure of firms to financing; the capital structure. None however attributed this to capital structure gearing levels which constituted a research gap to be filled by this study to add to the body of knowledge and literature. The capital structure gearing level is the proportion of external finance used in financing a firm. This proportion (gearing) may vary between $>0$ to $100 \%$.Some firms however have a proportion ranging between $>0$ and $<30 \%$ (LG), 30\%- $335 \%$ (MG1) $\geq 35 \%-<40 \%$ (MG2) $\geq 40 \%-\leq 60 \%$ (MG3) and $>60 \%$ (HG). The external finance may be inform of short term and long term debt and equity finance. Debt carries a fixed slice of earnings. High gearing (HG) will magnify the effect on earnings and hasten the process of insolvency. Poor financial performance and failure therefore maybe the result of inappropriate gearing level. This study sought to do the following: (i). Assess the capital structure of public and the private sector firms in Kenya's coastal counties. (ii). Assess the capital structure gearing levels of public and private sector firms in Kenya's coastal counties. (iii). Determine the effect of the capital structure gearing levels on financial performance of public and private sector firms in Kenya's coastal counties. This involved a target population of 500 productive firms in Kenya's Coastal Counties. Using the Cochran's sample size formula, 50\% proportion of the productive public and private sector firms randomly selected, the sample was 139 firms. They were observed for a period of 2003 to 2015. Questionnaires and structured interviews were used as instruments for collecting primary data from finance officers or finance managers or their equivalent of the firms. Secondary data was obtained from financial statements. Control variables were; size, tangibility and growth. Data analysis was done using both descriptive statistics and inferential statistics (regression).

The results showed that majority of the firms in Kenya's coastal counties used capital structure composed of short term debt financing, this implies that firms should go for capital structure with a higher component of long term finance. The firms had affinity for gearing and more affinity for higher gearing levels of over $30 \%$ whereas the optimum gearing level should be between $30 \%$ to less than 35\%.Firms in the Kenya's coastal counties should avoid higher gearing levels for better financial performance.
\end{abstract}

Keywords: capital structure, firms, public finance, private finance, public sector, private sector, gearing, poor financial performance 


\section{Introduction}

This section contains background to the study, statement of the problem, objectives, hypothesis, justification, assumptions, scope and limitations of the study.

\subsection{Background to the Study}

In the context of this study, firms are agencies of production. They are the producers and suppliers of goods and services consumed by the society. They include public sector firms or public sector undertakings and private sector firms. They are creation of the law. Their activities of production involve transactions such as procurement and payments, disposals (sales) and receipts etc. Ultimately their transactions and activities must translate to movement of cash (finance). Finance therefore is the heart and life blood of firm's transactions and activities (Ezra, 1969).

Firms have to employ capital in order to produce and supply goods and services. Capital employed by these firms is described as capital structure; the constitution of the capital employed. If the capital structure does not incorporate external finance, it is ungeared. However, if the capital structure in corporates external finance, it is geared. An ungeared capital structure is a total of: share capital from ordinary shareholders and reserves: (a) revenue reserves (b) capital reserves. A geared capital structure is a total of; share capital from ordinary shareholders, reserves, share capital from preference shareholders and long term liabilities (debentures and/or short term liabilities) (Weston \& Brigham, 1979; Van Horne \& Wachowicz, 1995).

The proportion of external finance used in financing a firm is referred to as gearing. It may be derived from the ratio of capital with fixed returns (CWFR)-preference share capital and long term liabilities to the ratio of capital with varied return (CWVR)-share capital from ordinary shares or CWFR: capital employed (CE) or CWFR as a \% of capital employed. The gearing level vary between $>0$ and $100 \%$. Some firms however have $>0$ and $<30 \% \mathrm{LG}$, $30 \%-\leq 60 \%$ (MG) above $60 \%$ (HG).

Firms operate in uncertain environment (Markowitz, 1959). For this reason, firms may experience fluctuations in earnings. These fluctuations are occasioned by systematic (market) risk and unsystematic (random) risk. External finance in the form of debt in a capital structure carries a fixed slice of profits whether they are earned or not. Debt finance also carries with it a legal obligation that demands interest and principal must be paid. Persistent failure to meet these payments may lead to bankruptcy and to pay bankruptcy costs which may be in the form of direct bankruptcy costs. Alternatively, firms may avoid bankruptcy and instead incur indirect bankruptcy cost. Both of which are financial distress costs. In a dynamic environment firms are likely to experience fluctuations in earnings. A firm with high gearing could experience more violent fluctuations in earnings to its shareholders more than disproportionately (Pandey, 2011). A medium geared firm will experience fluctuations in earnings to its shareholders and threaten solvency but the fluctuation will be to a lesser extent. A low geared firm will experience fluctuations in earnings and threaten solvency but would be fairly safe. An ungeared firm will experience fluctuations in earnings but solvency will not be threatened. The firm will be safe.

High gearing therefore will magnify the variability of earnings and may threaten solvency of the firms as earnings may not be sufficient to cover all operations and payment of principles and interest to debt holders'. If that happens, the firm is insolvent. The values of its assets are equal to value of its debts. The equity value would be zero. Ownership of the firm would be turned over to debt providers who in turn could sell its assets to recover what they were owed in a process called liquidation.

Public firms which were set up in other parts of Kenya includes Kenya Taitex Mills, Cotton Ginnery of Kenya, East Africa Fine Spinners, Sera coating, Kenya Engineering Industry, KENATCO, Rivertex, KNTC, Kicomi, Mountex, Nyayo Bus Corporation, Kenya Railways, and Postal Corporations. Agricultural Development Corporations (ADC), KMC, Industrial and Commercial Development Corporation( ICDC), Kenya Industrial Estate (KIE), National Oil Corporation of Kenya(NOCK), Kenya Film Classification Board, East African Portland Cement, Kenya Broadcasting Corporation, Kenyatta National Hospital, Kenya civil Authority, South Nyanza Sugar, Nzoia Sugar, Pyrethrum Board of Kenya ,National Environmental Management Authority, Coffee Board of Kenya etc. Private sector firms which were set up includes Kenya Bus Nairobi Ltd, Akamba Bus Company, Eveready Kenya, Colgate Palmolive, Cadburys, Proctor and Gamble Kenya, Mumias Sugar, Pan paper Mills etc.

Some firms which were set up in Kenya's coastal counties between 1963 and 1980 includes Kenya Cashewnuts, Bura Irrigation Scheme, Kenya Bixa, Brollo Kenya, Mariakani Milk Scheme, Kenya Meat Commission (KMC), Kenya Safari Lodges and Hotels, Uchumi Supermarkets, National Water Conservation, National Museums of Kenya, Horticultural Crop Development Authority (HCDA). National Oil Corporation of Kenya (NOCK), Kenya 
Industrial Estate (KIE), Agricultural Finance Corporation (AFC) amongst others. Private sector firms which were formed include the Alliance Group of Companies, Ramisi Sugar, Kenya Bus Mombasa Ltd, Seifees Bakery, Daramsh Bus Company, Malindi Bus Company, Tana River Bus Company, TSS Bus, Coast Bus Ltd etc. Most of these firms have collapsed and liquidated. Most of these firms are either collapsed and liquidated, are ailing or have relocated.

As at 2015, there were 194 new public firms in the country which were in operations. Out of these, $46.4 \%$ had poor financial performance as measured by accounting and market ratios (return on equity and return on assets). About 35 state corporations including sugar firms and local authorities had more operating expenses than revenue. Postal Corporation of Kenya for example made KES2.6m revenues but had KES4.16 b in operating expenses. NOCK made KES22.95b in revenues but had KES $24.76 \mathrm{~b}$ in operating expenses. Most public firms recorded more expenses than revenue. Kenya Meat Commission for example had KES940m in debt, Pyrethrum Board of Kenya had KES863m debt, Uchumi had KES2.5b in debt, National Water Conservation had KES2.4 b in debt, and Coffee Board of Kenya had KES752m debt. Out of 194 state corporations, 35 of these collectively owed the government KES15.4 b in non-performing loans (Kenya's treasury department statement, 2015).

Overall, about $96 \%$ of the firms which were set up closed down by the end of their first year in operations (World Bank Report, 2010). The logical questions are; why did these firms perform poorly? And why did these firms fail?

Table 1 below is an extract of the financial performance of some public firms while Table 2 below is an extract of the level of debt held by some public firms.

Table 1. Financial performance of some public firms

\begin{tabular}{|c|c|c|c|}
\hline NAME & DEFICIT (KSHS) & REVENUE(KSHS) & OPERATING EXPENSES (KSHS) \\
\hline Kenyatta National Hospital & $718 \mathrm{~m}$ & $4.85 \mathrm{bn}$ & $12.39 \mathrm{bn}$ \\
\hline Kenya Civil Aviation & $113 \mathrm{~m}$ & $5.56 \mathrm{bn}$ & \\
\hline Kenya Broadcasting Corporation & $582.3 \mathrm{~m}$ & & \\
\hline Kenya Wildlife Services & $486.7 \mathrm{~m}$ & $3.046 \mathrm{bn}$ & \\
\hline Kenya Film Classification Board & $62 \mathrm{~m}$ & & \\
\hline Postal Corporation of Kenya & $1.58 \mathrm{bn}$ & & \\
\hline National Oil Corporation of Kenya & $395 \mathrm{~m}$ & $24.7 \mathrm{bn}$ & $22.95 b \mathrm{~b}^{*}$ \\
\hline East African Portland Cement & $1.58 \mathrm{bn}$ & & \\
\hline Kenya Safari Lodges and Hotel & $84 \mathrm{~m}$ & & \\
\hline National Environmental Management Authority & $401.9 \mathrm{~m}$ & & \\
\hline National Museums of Kenya & $10 \mathrm{~m}$ & $398 \mathrm{~m}$ & $1.16 \mathrm{bn}$ \\
\hline Mt Elgon Lodge & $1.6 \mathrm{~m}$ & & \\
\hline Kabarnet Hotel & $5.7 \mathrm{~m}$ & & \\
\hline
\end{tabular}

Source: Public financial report of state corporations, 2015.

*cost of sales only.

Table 2. Debt level in capital structure of some public firms

\begin{tabular}{lc}
\hline NAME OF THE COMPANY & AMOUNT/SIZE OF DEBT \\
\hline Uchumi & $2.5 \mathrm{bn}$ \\
Kenya Meat Commission & $940 \mathrm{~m}$ \\
National Water Conservation & $2.4 \mathrm{bn}$ \\
South Nyanza Sugar & $199 \mathrm{~m}$ \\
Nzoia Sugar & $168 \mathrm{~m}$ \\
Miwani Sugar Mills & $78 \mathrm{~m}$ \\
Miwani Sugar Company & $16 \mathrm{~m}$ \\
Kenya Industrial Estate & $423 \mathrm{~m}$ \\
Coffee Board of Kenya & $752 \mathrm{~m}$ \\
Water Resources Management Authority & $362 \mathrm{~m}$ \\
Pyrethrum Processing/Pyrethrum Board of Kenya & $863 \mathrm{~m}$ \\
\hline
\end{tabular}

Source: Public financial report of state corporations, 2015. 


\subsection{Statement of the Problem}

Published annual financial reports, surveys and ad hoc management reports attributed poor financial performance and failure of firms to many factors. These includes high cost of energy, intense competition, high cost of raw materials, obsolete equipment, poor management, poor technical skills, high cost of finance and other bank charges, inadequate finance, family feuds, lack of succession plan etc. Some empirical studies attributed poor performance and failure of firms to financing; the capital structure. None however attributed this to capital gearing level. This, in the researchers view constitutes a research gap to be filled by this study to add to the body of knowledge and literature.

The capital structure which is the constitution of the capital employed has significant effect on earnings and solvency of a firm in risky environment (Brealey \& Myers, 1991). In the researcher's view, the proportion of external finance which is gearing may vary as follows; $>0-<30 \%$ low gearing(LG), $30 \%-<35 \%$ medium gearing (MG 1), $\geq 35 \%-<40 \%$ medium gearing (MG2), $\geq 40 \%-\leq 60 \%$ medium gearing (MG3) and $>60 \%$ high gearing (HG) have effects on financial performance of firms.

The proportion of external finance has fixed cost therefore a fixed slices of earnings. Different gearing levels carry different fixed costs therefore different slices of earnings. High gearing has more fixed costs and more slices of earnings effectively magnifying the effect on earnings and hasten the process of insolvency.

\subsection{Objectives of the Study}

\subsubsection{General Objectives}

The general objective of this study was to determine the effect of capital structure gearing levels on the financial performance of public and private sector firms in the Kenya's coastal counties and how these capital structure gearing levels contributed to poor financial performance and/or failure of firms.

\subsubsection{Specific Objective}

The specific objective of this study were:

1) To assess the capital structures of public and the private sector firms in Kenya's coastal counties.

2) To assess the capital structure gearing levels of public and private sector firms in Kenya's coastal counties.

3) To determine the effect of the capital structure gearing levels on financial performance of public and private sector firms in Kenya's coastal counties.

\subsection{Hypothesis}

This study was premised on five hypothesis;

H1; Low capital structure gearing level (LG $0-<30 \%$ ) had no significant effect on the financial performance of public and private sector firms.

H2; Medium capital structure gearing (MG130\%-<35\%) had no significant effect on the financial performance of public and private sector firms.

H3; Medium capital structure gearing (MG2 $\geq 35 \%-<40 \%$ ) had no significant effect on the financial performance of public and private sector firms.

H4; Medium capital structure gearing (MG3 $\geq 40 \%-\leq 60 \%$ ) had no significant effect on the financial performance of public and private sector firms.

H5; High capital structure gearing ( $\mathrm{HG}>60 \%)$ had no significant effect on the financial performance of public and private sector firms.

\subsection{Justification of the Study}

The empirical studies which had been conducted focused on the determination of the influence of debt on financial performance of listed firms. However, the effects of the level of capital structure gearing of listed and unlisted firms and the effect of the level of gearing; low, medium or high on financial performance of listed and the unlisted firms were not considered.

Further, the studies which were conducted emphasized on firms which were listed at stock exchanges and these were the good performing firms because only good performing firms were listed at the stock exchange. The unlisted firms which may be poor performing firms were not included in those studies.

This study however focus on firms which were excluded so that it can add to the body of knowledge and literature and to help investors and also the productive firms in the Kenya's coastal counties to improve their 
financial performance .The region and its population would also benefit from this study as the findings will help to improve the productive capacity, income, employment and a higher scale of living and lower poverty levels.

\subsection{Assumption of the Study}

The study was carried out on the assumption:

a. That all the respondents would give accurate responses to the questionnaires and interviews.

b. That financial information preparation was within acceptable standards (IFRS).

c. That financial information of limited liability firms was accessible to parties with interest.

\subsection{Significance of the Study}

The study aimed to benefit various groups of interest which included the owners of firms, bankers, government, capital market authority, stock exchange, lenders, investors, managers etc. in making financing decisions to finance their businesses

\subsection{Scope of the Study}

The scope of this study was limited to the capital structures of 139registered limited liability public and private sector firms in Kenya's Coastal Counties.

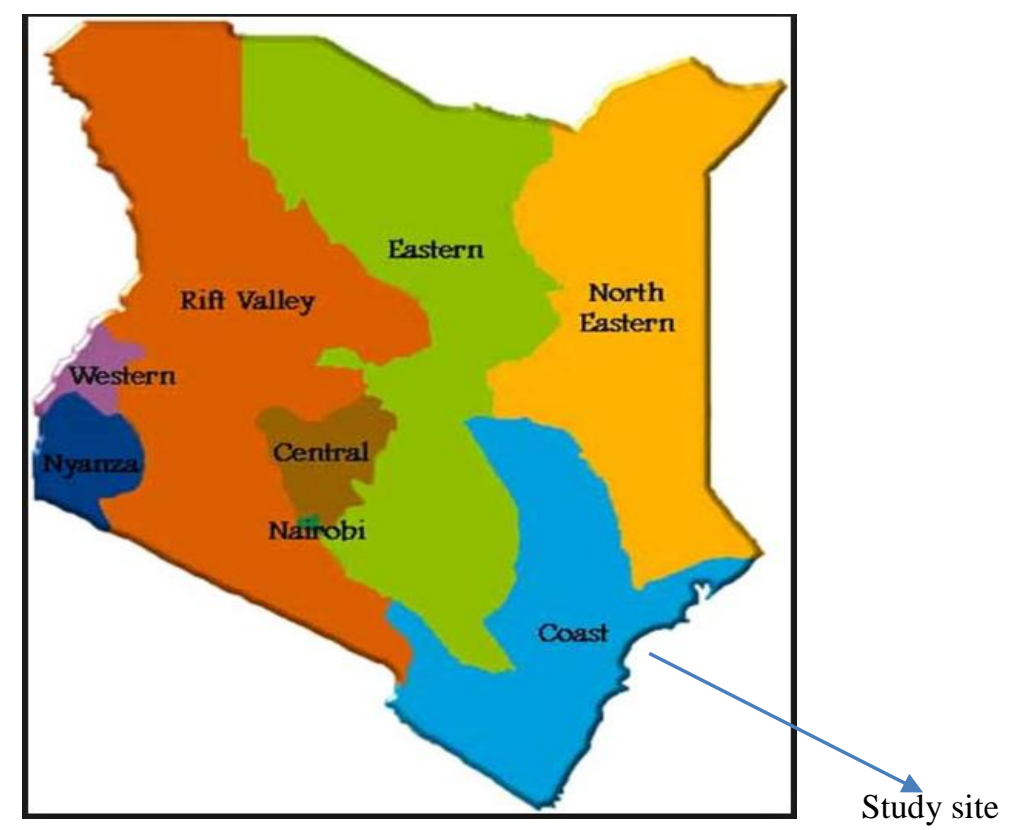

Figure 1. Map showing the location of Kenyan Coast

\subsection{Limitations of the Study and Mitigation Measures}

From the study, financial performance is a function of many factors some of which were not investigated in this study. For example the effect of gearing levels on financial performance of firms by sectors. This study was only limited to the general and specific objectives namely; assess capital structure, assess capital structure gearing levels and determine the effect of capital structure gearing levels on financial performance of firms in Kenya's Coastal Counties.

Further financial performance analysis requires a review of conforming firm's financial data. While public and listed firms have financial data which tend to conform to the accepted nationally and internationally accounting standards and conventions, this may not be so for financial data presented by a big percentage of unlisted private limited firms.

Most of unlisted private limited firms in the coastal counties were family owned. Although private firm's managers did not explicitly state that creative accounting was practiced, there was this possibility. Such financial information may not be accurate and could lead to wrong conclusion as such financial data when used in deriving ratios may produce inaccurate results. To mitigate this, the data received was verified by confirming the financial data given by the firm from the published audited financial statements signed by a certified public 
accountant, verifying the deposits made from the bank statements issued by the bank and the tax records were also used to compare the income and expenses listed on the tax returns against the information given from the financial statements.

\section{Literature Review}

The chapter covered literature on capital structure of firms and influence on the financial performance of firms at both international and national level.

\subsection{Theoretical Framework}

The study was based on the following theories: MM theory, trade off theory, agency theory and market timing theory.

\subsubsection{MM theory (Modigliani and Miller)}

This theory states that in a perfect market where there are no taxes and no transaction cost, the value of a levered firm (with debt) and that of an unlevered firm (without debt) is the same (Modigliani \& Miller, 1958).

This was explained in their MM proposition I and MM proposition II. In proposition I, they considered two firms with identical assets, operated in same market segment and had same market share. Since the two firms belonged to the same industry and faced similar competitive and business conditions and exposed to similar business risk, they were expected to have same net operating income.

It is logical to conclude that investors expected rates of return; opportunity cost of capital of the two identical firms would be identical irrespective of whether the firms were all equity financed or one firm was wholly equity financed and one firm had a 50\% equity and a 50\% debt or other financing combination mix.

MM proposition I is that firms with identical net operating income and business (operating) risks but different capital structure should have the same value. Firms in the same risk class, their total market value is independent of financing mix (debt equity) but by capitalizing the expected net operating income by the capitalization rate (opportunity cost of capital) which is the same for both geared and ungeared firm. Under arbitrage process (switching), investors will engage in personal or homemade gearing against corporate gearing. This would restore equilibrium in the market therefore the market value of the firm would not be affected by gearing. The financing (capital structure) decision in this case is irrelevant. It did not help in creating any wealth for the shareholders neither did it affect the financial performance of the firm.

Financial gearing however affects shareholders return (EPS and ROE). The purpose of gearing is to increase a firms value (Bierman \& Hausman, 1970). Earnings per share and return on equity increases with gearing when the interest rate paid is less than the firms return on assets. Financial gearing also increases shareholders financial risk by amplifying the variability of Earnings per share and return on equity (Solomon \& Pringel, 1978). In this case, financial gearing causes two opposing effects; increases the shareholders return and also increases the financial risk. Shareholders will therefore increase the required rate of return (cost of equity) on their investments to compensate for their financial risk. The higher the financial risk therefore, the higher the shareholders required rate of return or cost of equity. This is the MM's proposition II. For an ungeared firm therefore, its opportunity cost of capital is equal to its cost of equity. The opportunity cost of capital for a geared firm will remain constant as the cost of equity will increase to offset the advantage of cheaper cost of debt so that the opportunity cost of capital does not change (Modigliani \& Miller, 1958).

The MM's theory however is based on a critical assumption that corporate income taxes do not exist. This assertion however is unrealistic in that there is no country that has no corporate taxes. In reality corporate income taxes exist and interest paid to debt holders is tax deductible expense. Interest payable by firms therefore saves taxes. This makes debt financing advantageous (Brealey \& Myers, 1991). The value of a firm therefore will increase with debt due to the deductibility of interest charges for tax computation. The value of a geared firm therefore will be higher than that of an ungeared firm but earnings to shareholders will be reduced by personal taxes (Modigliani \& Miller, 1963).

After the traditional theory and the MM theory, other major theories of capital structure have since emerged; the trade off, the pecking order, agency and market timing.

This theory is relevant to the study in that is it about gearing of a firm. It explains how the value of a geared or ungeared firm is the same from an investor's point of view

\subsubsection{Trade Off Theory}

This theory postulates that a firm may choose how much debt finance and how much equity finance to use by 
balancing the costs and benefits of each since most firms are financed by partly debt and partly equity.

Capital structure is the constitution of the firm's capital employed while gearing is the proportion of external finance used in the financing of a firm (Brealey \& Myers, 1991).

Gearing has significant effects on the earnings and solvency of a firm. The gearing may vary from ' 0 ' no gearing, $\langle 30 \%$ low gearing, $\geq 30 \%$ and $\leq 60 \%$ medium gearing or $>60 \%$ high gearing.

From the earnings per share (EPS) point of view, the best capital structure is one that is high on debt. EPS will be highest with high debt. The best capital structure therefore is one which high on debt at least $100 \%$.The advantage is that earnings per share is high, possibly dividends will be high and the control of the firm shall not be affected and debt is a cheaper form of finance in that interest on debt is tax deductible (Modigliani \& Miller, 1963).

In practice however, firms do not borrow 100\%. Personal tax on interest income reduces the attractiveness of debt (Miller, 1991).

There are other corresponding disadvantages of debt. These are classified as financial distress (Brealey \& Myers, 1991). Financial distress arise when a firm is not able to meet its obligations (payment of interest and principal) to debt holders. The firm's continuous failure to make the payments to debt holders can ultimately lead to the insolvency of the firm.

Firms operate in uncertain environment (Markowitz, 1959). They are faced with systematic (market) risk originating from changing conditions of the general economy and unsystematic (random) risk originating from changing conditions of the firm itself. The expected earnings may not turn out as expected. For a given level of operating risk, financial distress is magnified with higher debt. With higher business risk, the probability of financial distress becomes much higher.

The degree of business risk of a firm depends on the degree of operating leverage; proportion of fixed costs, general economic conditions, demand and price variations, intensity of competition, extent of diversification and maturity of the industry. There will be higher operating risks for firms operating in turbulent business environment and in highly competitive markets and even higher operating risks for firms that are highly capital intensive and have high proportion of fixed costs. Depressed earnings and insolvency of these firms therefore will be higher.

Persistent financial distress may ultimately force a company into liquidation and to pay direct costs of insolvency; legal and administration costs involved in transfer of ownership to debt providers, and the cost of keeping the firm in operation while accountants, lawyers, bankers, and others haggle over the case in court as transfer is a legal process not an economic process.

Because it is expensive to go bankrupt, firms will avoid a bankruptcy filing. They will restructure their firms operations and businesses. They may decide to divest, reduce workforce, etc. These are indirect costs of bankruptcy. There will also be other costs related to actions by employees, managers, customers, suppliers, shareholders and agency costs. The direct and indirect bankruptcy costs; financial distress costs may also be called bankruptcy tax. In considering new finance therefore, a firm will be faced with trade off; to choose debt that saves the firm corporate tax or more debt to the firm and face financial distress and to pay bankruptcy costs or tax (Brealeys \& Myers, 1991).

This theory is very relevant to the study .Ordinarily, firms will use internal sources of finance and when the internal finances are depleted, a firm goes for external finance. In the external sources of finance, debt is one of those alternatives but how much debt a firm should acquire is a matter that management must decide. A firm will face a tradeoff between debt that saves the firm's corporate taxes and debt that will lead a firm into insolvency and to pay financial distress cost. This study is about the gearing/debt levels a firm can acquire and the debt levels where financial performance is best.

\subsubsection{Agency Theory}

Agency theory explains about the conflict that may arise between managers and owners of the firm. This conflict may give rise to agency costs. It occurs where firms may have wide ownership and it becomes impossible to have all owners at one central place to run the operations of the firm. Control of the firm therefore will be effectively in the hands of management. This creates agency relationship. Because of varied interest between managers and shareholders, there will be conflict of interest. This will give rise to agency problems. Manager sought to act in the best interest of the shareholders, however they may not. They will incur an expenditure which does not add value to owners. They will not undertake an investment which they consider as risky 
investment endangering their job security yet it could be beneficial to the owners. This will give rise to agency costs; direct agency costs; an expenditure that does not benefit the owners and payments made to auditors who will monitor actions of managers, and indirect costs in form of lost opportunities.

Debt in the capital structure expose a firm to insolvency and lose of job security. With debt therefore, managers are likely to be disciplined thereby reducing agency problems and costs. Interest on debt is tax deductible. It will increase expenses and by extension reduce profits and surplus cash. Effectively this reduces agency costs (Jensen \& Meckling, 1976; Suleiman, 2013).

Agency theory is relevant to this study in that it is about debt which is a deterrent, debt levels and debt level where financial performance is best. Managers are fearful for their jobs security therefore under debt they are most likely to minimize the agency cost.

\subsubsection{Pecking Order Theory}

This theory postulates that firms would prefer to use one type of financing over another because the cost of financing increases with asymmetric information. A sin siders, managers of a firm have asymmetry information about the past, the present and future of their firms than investors (Myers \& Majluf, 1984). They are also aware of various types of finance from which they can choose from; internal finance share capital (reserves),external finance, internal equity, external equity and long term liabilities(debentures and loans) etc. They are aware that each form of finance has benefits and costs. Some finance carries legal obligation to repay with interest and other charges while other financing have a permanent cost like dividends to be paid but it's not a legal obligation. Some finance has higher exposure to financial distress and high probability to pay financial distress costs.

In essence, every finance has advantages and disadvantages. Some finances have more advantages than others. Based on these, some finance are more superior to others and can be ranked one on top of the other in a pecking order.

Because of asymmetric information, managers will consider new finance for their firms based on their view of their firm's future prospects. They will always use superior internal finance and issue debt which has high exposure to insolvency therefore risky finance to firms when they are positive about their firm's future prospects. They will however issue equity which has less exposure to insolvency when they are unsure. Therefore, a firm will raise new finance in a pecking order form (Myers \& Majluf, 1984). The firm will always use the safest finance (internal finance) first, if the finance is not available, they will issue debt in the following order: Issue secured debt first, Issue unsecured debt and thirdly Issue hybrid securities

As a last resort, they will issue shares to raise finance but first they will issue rights issues to raise internal equity or issue rights issue and IPO to raise both internal and external equity.

Pecking order theory is very relevant to the study .Ordinarily, firms will use internal sources of finance and when the internal finances are depleted, a firm goes for external finance. In the external sources of finance, debt is one of those alternatives. This study is about the gearing/debt levels a firm can acquire.

\subsubsection{Market Timing Theory}

Market timing theory of Baker and Wurgler (2002) postulates that firms time their equity issues. They will issue new stock when the stock price is perceived to be overvalued and repurchase their shares when there is an undervaluation of the price (Luigi \& Sorin, 2009). As a result, fluctuation in stock prices will affect firm's decision on capital structure.

Equity markets indicators therefore are important element of real corporate financial policy on issuing equity. Low leverage firms are those which raised funds when their market valuation were high, based on market-to-book ratio. High leverage firms are those which raised funds when their market valuation were low. There are however two versions of equity market timing.

The dynamic version of Myers and Majluf (1984) which is based on rational managers and investors explains that managers are expected to issue equity directly after a positive information release. This reduces the asymmetry problem between the firm's management and stockholders. The decrease in information asymmetry will result to an increase in the stock price (Luigi \& Sorin, 2009). This theory indicates that firms create their own timing opportunities to finance their projects. There is adverse selection across firms or across time. This is inversely related to the market-to-book ratio.

The irrational managers and investors of Baker and Wurgler (2002) explains that managers issue equity when they believe its cost is irrationally low and repurchase equity when they believe its cost is irrationally high (Baker \& Wurgler, 2002; Luigi \& Sorin, 2009). This version does not require that the market actually be efficient 
and it does not ask managers to successful predict stock returns (Luigi \& Sorin, 2009).

Market timing theory is relevant to this study in that it articulates the best time when debt should be issued.

\subsubsection{Summary of the Theories to This Study}

Overall, all the theories explained above were relevant to this study. However the tradeoff and the pecking order theory were most relevant for this study. Capital structure issue is an ongoing process. It evolves in response to needs of firms.

In the normal course of business, firms build internal reserves as a source of finance to finance their operations because it is cheaper than debt and equity. Firms use internal reserves first. Where internal reserves are not available, firms seek external sources of finance to finance their operations. Therefore firms use external sources of finance only when their internal reserves are not available or sufficient. This is where the pecking order theory was relevant.

The external sources of finance could be friends and family, gentlemen in dark glasses, members of the company, partners in the partnership and financial markets and institutions. Irrespective of the source of external finance all external finance had costs and benefits. When choosing new finance, firms are faced with a tradeoff between debt which saves the firm corporate taxes and more debt to the firm to pay bankruptcy costs which amount to bankruptcy tax. This is where the tradeoff theory was relevant.

\subsection{Empirical Literature and Methodological Approach}

Some studies have been conducted to establish the relationship between capital structure and firm's financial performance and also gearing, gearing levels and the firm's financial performance. Both groups of studies produced varying results. Some researchers produced positive relationship, some produced negative relationship, while others produced mixed or no relationship between capital structure and firms financial performance.

Some contributions in the literature related to the relationship between capital structure and firms financial performance that found a positive, negative or mixed results are outlined below:

Githire's (2015) study on the effects of capital structure on financial performance of firms listed at NSE in Kenya which adopted an explanatory none experimental research and used SPSS and multiple regression analysis model found that equity and long term debt in capital structure had a positive and significant effect on financial performance while short term debt had negative insignificant effect on financial performance. The study concluded that equity and short term debt financing enhanced financial performance while short term debt reduced financial performance. The study was however on effects of capital structure on listed firms.

According to Lavorskyi (2013), the relationship between leverage and firm performance was negative. This study was on the impact of capital structure on firm performance in Ukraine. The result was not consistent with the tradeoff theory but supported the validity of the pecking order theory. The study investigated the relationship between capital structure and firm performance.

The study of the influence of capital structure on firm's performance on 36bangladesh firms listed in Dhaka stock exchange that was based on four performance measure and using panel data regression method found that EPS was significant positively related to short term debt while significant negatively related to long term debt .The conclusion was that capital structure had negative impact on firms performance which was consisted with the pecking order theory (Bokhtiar et al., 2013).

Mahfuzah et al. (2012) study of capital structure and firm performance on 237 Malaysian listed companies used four performance measures and panel data procedure on five capital structure measures and found that firm's performance measured by ROA, ROE and EPS had negative relationship with short term debt, long term debt and total debt as independent variables. There was however a positive relationship between growth and performance in all sectors. The study concluded that total debt has significant negative relationship with the performance of the firm.

According to Lawal et al. (2014) on the investigation of the effects of capital structure on firm's performance on manufacturing companies in Nigeria found that capital structure, total debt and debt to equity ratio were negatively related to firm performance and recommended that firms use more equity than debt in financing their business activities in as much as the value of the business can be enhanced using debt capital. The study examined the effect of capital structure on firms' performance using descriptive and regression research technique and considered performance ratios of return on assets and return on equity and total debt to total assets and total debt to equity on firm's performance.

Nirajini et al. (2013) study on impact of capital structure on financial performance of listed trading companies in 
Sri Lanka e found that capital structure was significantly impacted on the financial performance of the firm and that debt asset ratio, debt equity ratio and long term debt correlated with GPM, NPM, ROCE, ROA and ROE at significant level of 0.05 and 0.1.The study examined the relationship between capital structure and financial performance using correlation and multiple regression analysis and found a positive relationship between capital structure and financial performance.

Using panel data consisting of 257 South African firms over the period 1998 to 2009, Samuel (2013) investigated the association between capital structure and firm performance. To test the relationship, the study used GMM regression approach and found a positive and significant relation between financial leverage and firm's performance. Aliakbar et al. (2013) also found a significant positive link between capital structure and firm performance in the Tehran Stock Exchange

Allen's (2002) study found that data on US banking industry were consistent and the results were statistically and economically significant. However, the US banking industry that the researcher looked at is different from the productive public and private firms in Kenya's coastal counties. This was a study on capital structure and firm performance in US banking industry that used simultaneous equation mode to find how leverage in capital structure affected agency costs and firm performance.

A study of capital structure and firms' performance in Vietnam that examined the impact of capital structure on firm's performance in selected 147 firms listed on HCMC stock exchange checked the impact of level of leverage on firm's performance and found it to be negative. The study also checked short term and long term debt ratios to see the effect of debt maturity on firm's performance and they found no difference between short term and long term debt. However, the study found that there was negative relationship with very high proportion on average with debt. (Tristan et al., 2015).

According to Anup and Suman (2010), maximizing the wealth of shareholders demands a perfect mixture of debt and equity, whereas cost of capital had a negative correlation and it has to be as least as possible. The results were obtained when they examined the link between capital structure and firm value in Bangladesh. Other authors also witnessed significant negative relation between profitability and leverage in Bangladeshi firms

(Tristan et al., 2015; Khairul, 2013). Roden and Lewellen (1995) found a positive relation between profitability and capital structure when they employed a sample of 48 U.S firms during 1981-1990. Analogous results were also observed by champion (1999); Ghosh et al. (2000); Hadlock and James (2002).The studies concluded that highly profitable firms used high-level of debts.

Salim and Yadav (2012) studied the relationship between capital structure and firm performance using a sample of 237 Malaysian companies during 1995-2011 and revealed that firm performance measured by ROA, ROE and EPS had negative relationship with the capital structure while Tobin's Q has significantly positive relationship with STD and LTD. Similar result was also observed by Zeitun \& Tian, (2007) on their study for a sample of 167 Jordanian companies during 1989-2003.

Abor's (2005) study revealed a significantly positive relation among ROE and the short term debt and total debt ratio, while a negative relation with long term debt .The study investigated the link between capital structure and profitability of firms listed in Ghana Stock Exchange for the period 1998-2002.

Phillips and Sipahioglu's (2004) study documented no significant link between capital structure and firms performance for publicly traded UK lodging firms; lodging firms seem to prefer external sources as capital return was at a low level.

Tianyu's (2013) study on the influence of capital structure on firm's performance in both developed and developing markets revealed that capital structure had a significant negative effect on firm's performance in China and a significant positive effect in two European Countries, i.e. Germany and Sweden, before financial crisis in 2008.

A sample of 1200 listed firms in Germany and Sweden and 1000 listed firms in China for the period 2003-2012 had been used in his study. Applying OLS regression method, Ali and Iman (2011) observed that firm's performance, calculated by EPS and Tobin's Q was positively related with the capital structure, while they got a negative relation between capital structure and ROA. However, the study witnessed no significant relationship between ROE and capital structure .Same result was also found by (Ebrati et al., 2013).

Ibrahim's (2009) study on the influence of capital structure choice on firm performance in Egypt found that firm performance had weak to no relationship with capital structure choices. This study was based on a sample of non-financial listed firms for the period 1997 to 2005 and used multiple regression analysis. Likewise, Khalaf (2013) also found negative and insignificant relationship between short term and long term debt ratio and ROA 
and profit margin.

Other contributions in the literature related to the relationship between gearing, gearing levels and firms financial performance that obtained positive, negative or mixed results are as follows;

Dude's (2013) study of the impact of debt financing in the capital structure of small and medium firms (SME's) in Zimbabwe showed that debt finance had a positive impact on productivity of firms. This study did not consider financial performance of the firms.

Another study was on the impact of gearing on performance of companies. It was done to ascertain the roll gearing play in the performance of selected companies in Nigeria. Three research hypothesis were raised and tested. The hypothesis were tested using t-test statistics at a significant level of 5\%.The testing of the hypothesis revealed that efficiently managed gearing could lead to increase in earnings of the company. In the finding, Siyambola (2015) study found that gearing had direct relationship with the performance of the company and that gearing provided some advantages with positive impact on profitability.

Harwood's (2015) investigation on the effects of debt on firm's performance on commercial banks listed in Nairobi securities exchange that sought to find out whether use of debt in a firms debt structure affected firm's performance found that debt negatively affected firm's performance though not statistically significant as measured by return on assets. The study concluded that use of debt in firms' capital structure negatively affected the performance of commercial banks in Kenya. The study used longitudinal research designs in collecting data on target population of 11 commercial banks using SPSS version 16.0 and inferential statistics; correlation and regression mode.

A significant positive relation between leverage and firms performance was observed by Margaritis \& Psillaki (2010), The study used a sample of both low and high growth French firms for the period 2003-2005 and found that leverage have positive effect on firms efficiency over the entire sample.

Gleason, Lynette, and Ike (2000) concluded that high levels of debt in the capital structure reduced the firm's performance. The study observed that firm's capital structure had a statistically significant negative effect on firm's performance matrixes, i.e. return on assets (ROA), Growth in sales (Gsales), and pretax income (Ptax).

Manawaduge et al. (2011) concluded that most of the Sri Lankan firms employed short term debt capital as against the long term debt and firm performance was negatively affected by the use of debt. Similar result was also noticed in Nigeria by (Amos \& Jeremiah, 2013). In addition, the study documented that firms use retained earnings first, then debts and finally equity.

Nor and Fatihah (2012) tried to explore the impact of debt and equity financing on the performance of the firms listed in Bursa Malaysia. Using a sample of 130 firms for the period 2001-2010 combined with multiple regression analysis, the study cited a statistical significant negative relation between capital structure and firms performance.

Kinsman and Newsman (1998) studied the relationship between debt level (including three measures of debt level) and firm's performance and detected diverse results. This study found that earnings are negatively correlated with short-term debt, but are positive with long term debt. A similar result was found in Brazil by Mesquita and Lara (2003)

The empirical studies mentioned focused on effects on capital structure; short term and long term debt on financial performance of listed firms. They used descriptive statistics and inferential statistics approaches. This study focused on effects of gearing levels (debt levels) on financial performance of firms both listed and none listed firms.

The focus of this study though slightly different had similar theme and also used a combination of descriptive and inferential statistics.

\subsection{Gaps and Brief Critique}

Extensive empirical research had been conducted to establish the relationship between capital structure and debt on financial performance of firms in different countries. Kenya however had little contribution in this literature. Also, capital structure formation behavior in developed countries was different from that of emerging, middle and least developed countries. Kenya a least / middle developed nation had capital structure formation behavior peculiar to her own situation.

A brief overview of the researches that were conducted showed similarities in focus. Most of them had focused on how or whether capital structure affected financial performance of firms and Kenya had very little contribution in this literature and this constituted a research gap to contribute to body of knowledge and 
literature.

Some empirical studies undertaken examined the influence of debt in the capital structure on financial performance of firms which were listed at the stock exchanges. For firms to be listed at the stock exchange, they require to offload a basic minimum of $25 \%$ of their shares and to have a share capital of between KES 20M and KES 50M as one of the requirements and only good performing firms could meet this requirement. This was a focus on good performing firms since only good performing firms are listed at the stock exchange. It excluded the poor performing and unlisted firms and this constituted a research gap.

No empirical studies had focused on the effect of the level of gearing; low, medium or high on financial performance. This also constituted a research gap. This study intended to determine the effects of gearing levels on financial performance of both listed and unlisted and good performing and poor performing firms to fill the research gaps to add to the body of knowledge and literature,

\subsection{Conceptual Framework}

Figure 2 is a conceptual framework that explains the relationship between the dependent, intervening and independent variables of the study.

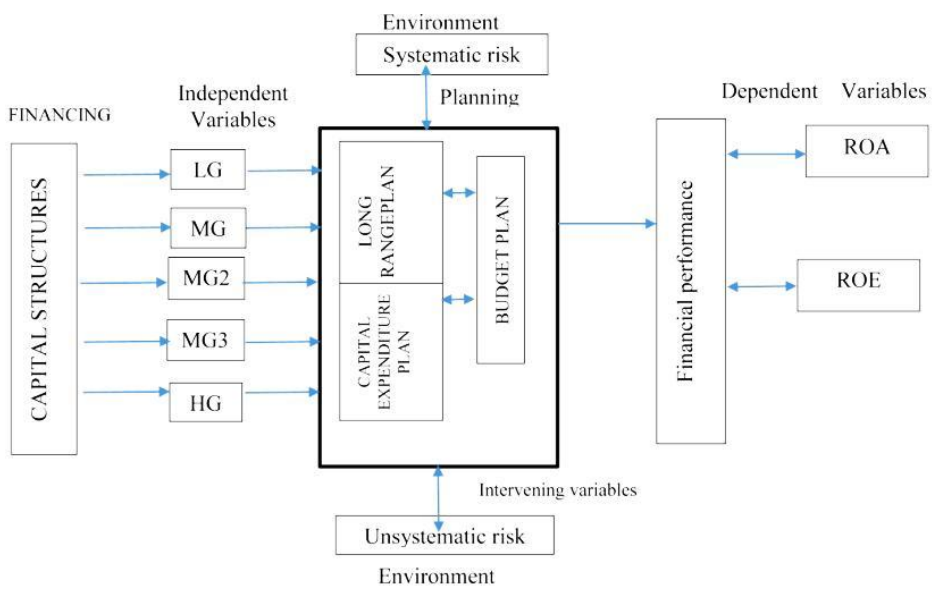

Figure 2. Conceptual framework

Source: Author's own formulation.

Firms operate under risky environment. In this environment there is systematic risk originating from changing economic conditions and unsystematic risk originating from changing conditions of the firms themselves. To survive and prosper under this risky condition the firms must forecast. This plan includes long range planning and capital expenditure planning. The two are expressed in numerical (financial) terms in budgetary planning as a budget; an action plan. These were the intervening variables.

The action plan was implemented through transactions (procurement and payments), disposals (sales) and receipts .Ultimately, transactions translated to movement of cash (finance). This was the financing/capital structure decision. The financing could be of lower gearing (LG), medium gearing (MG1), medium gearing (MG2), medium gearing (MG3) or high gearing (HG). These were the independent variables. The outcome of the action plan after implementation was the financial performance which was measured by return on equity and return on assets. These were the dependent variables.

\subsection{Summary}

This study focused on effects of levels of gearing on financial performance of the firms. This study sought to test the hypothesis that gearing levels; LG, MG1, MG2, MG3and HG had no effect on the financial performance of the firm.

\section{Research Methodology}

This chapter presents data and methodology used in the study. It includes the design, target population, sample design, data collection, instruments/tools, data collection procedures and techniques.

\subsection{Research Designs}

The study adopted a descriptive research design. Some previous studies that used a similar approach to obtain their findings are Lawal et al. (2014), Nor and Fatiha (2012), Salim and Yadav (2012). 


\subsection{Study Sites}

The study was carried out on the capital structures gearing levels of public and private sector firms in Kenya's coastal counties; Mombasa, Kwale, Kilifi, Tana River, Lamu, and TaitaTaveta. These counties have exhibited a high level of firm's failure compared to other counties in Kenya. The map showing the study site is shown below.

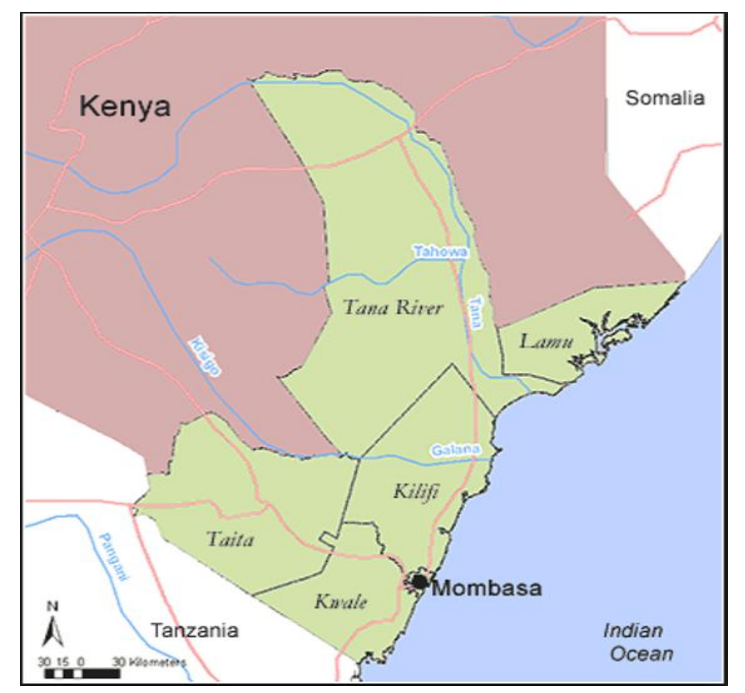

Figure 3. Study sites

Source: Coastal Kenya Atlas Map.

\subsection{Target Population}

The target population was 500 productive limited, listed and unlisted public and private sector firms. The list of firms was available at the government desk in the Huduma Centre and state Department of trade and industry Kenya.

\subsection{Sample Size}

From the target population of 500 productive public and private sector firms in the Kenya's coastal counties, Cochran's size formula with confidence level of $95 \%$ and a margin of error of $5 \%$, a proportion or distribution was $50 \%$, the sample size was 139 firms selected from computer generated random sample.

Cochran's size (Bartlett et al., 2001) formulae;

$$
N o=\frac{z^{2} p q}{e^{2}}
$$

where is the desired level of precision, margin of error $(5 \%), p$ is the estimated proportion of the population which has the attribute in question (50\%), q is 1-p and $\mathrm{z}$ value is found in $\mathrm{z}$ table where a $95 \%$ confidence level gives us $\mathrm{z}$ values of 1.96.A 95\% confidence level was used because it provided a range of values which was likely to contain the population parameter of interest.

The sample size of 139 productive public and private sector firms was observed over a period of 2003 to 2015 .

\subsection{Sampling Technique and Proportion}

The sample of 139 firms involved in producing goods or services was randomly selected from a frame of 500 registered, limited, listed or unlisted private and public firms. They were in 73 sectors in Kenya's coastal counties. The generation of the sample firms was proportionate and was by the use of computer generated random sample. This was to ensure there was a representative sample of firms. Mombasa County being the main host of both public and private sector firms within the coastal county region had about $75 \%$ therefore contributed $75 \%$ of the sample firms (104 firms), followed by Kilifi County accounting for $12 \%$ of the sample firms (17 firms), followed by TaitaTaveta County accounting for $6 \%$ of the sample firms ( 8 firms), Kwale County accounting for $3 \%$ of the sample firms (4 firms) and the balance of $4 \%$ (6 firms) is shared equally by Tana River and Lamu County. 


\subsection{Data Collection Instruments}

Primary and secondary data was used in this study. The primary data was obtained using a self-administered structured questionnaire. Secondary data was obtained from financial statements.

\subsection{Validity and Reliability of Instruments}

To ensure validity of the study, the instrument used for data collection was subjected to a pilot test run survey conducted in some firms in Mombasa County to test the effectiveness of this research instrument on a randomly selected survey participants.

\subsection{Data Collection Procedure}

The researcher and data collection assistants administered the questionnaires to the respondents using two methods; drop and pick letter and direct interview on appointment. The selected firms were visited and the questionnaires administered to the respondents.

\subsection{Ethical Consideration}

The initial questionnaire had name slots for firm's details. The respondents (finance managers of most firms) were however reluctant to give financial information alongside firm's details citing sensitivity and confidentiality of the information sought. To address the ethical issues, the researcher and the respondents agreed that firms details and names of respondents would not be quoted anywhere in the report. Therefore the questionnaire had to be revised to expunge these sections as shown in the appendix three. The respondents were also assured that strict confidentiality would be maintained in dealing with the responses.

\subsection{Data Analysis and Presentation}

The data was analyzed using the descriptive statistics and inferential statistics (regression analysis).

Objective one which sought to assess the capital structure of public and the private sector firms in Kenya's coastal counties used descriptive statistics to analyze data.

Objective two which sought to assess the capital structure gearing levels of public and private sector firms in Kenya's coastal counties used descriptive statistics to analyze data

Objective three which sought to determine the effect of the level of capital structure gearing on financial performance of public and private sector firms in Kenya's coastal counties used both descriptive and inferential statistics (regression analysis) to analyze data.

In order to test the hypothesis concerning the effect of gearing levels (independent variables) on financial performance (dependent variables), the gearing levels which are low gearing, medium gearing one, medium gearing two, medium gearing three and high gearing gave rise to five models for return on equity and five models for return on assets as a set as specified below;

$$
\begin{aligned}
& \mathrm{ROE}=\mathrm{f}(\mathrm{LG}+\text { tangibility }+ \text { size }+ \text { growth }) \\
& \mathrm{ROE}=\mathrm{f}(\mathrm{MG} 1+\text { tangibility+size+growth) } \\
& \mathrm{ROE}=\mathrm{f}(\mathrm{MG} 2+\text { tangibility }+ \text { size }+ \text { growth }) \\
& \mathrm{ROE}=\mathrm{f}(\mathrm{MG} 3+\text { tangibility }+ \text { size }+ \text { growth }) \\
& \mathrm{ROE}=\mathrm{f}(\mathrm{HG}+\text { tangibility }+ \text { size }+ \text { growth }) \\
& \mathrm{ROA}=\mathrm{f}(\mathrm{LG}+\text { tangibility }+ \text { size }+ \text { growth }) \\
& \mathrm{ROA}=\mathrm{f}(\mathrm{MG} 1+\text { tangibility }+ \text { size }+ \text { growth }) \\
& \mathrm{ROA}=\mathrm{f}(\mathrm{MG} 2+\text { tangibility }+ \text { size }+ \text { growth }) \\
& \mathrm{ROA}=\mathrm{f}(\mathrm{MG} 3+\text { tangibility }+ \text { size }+ \text { growth }) \\
& \mathrm{ROA}=\mathrm{f}(\mathrm{HG}+\text { tangibility }+ \text { size }+ \text { growth })
\end{aligned}
$$

The purpose of using individual gearing levels was to establish which among the gearing levels will the firm have the best financial performance. Microsoft excel was used to perform the statistical calculations required for this study.

The general model was formulated as follows:

$$
\mathrm{Y}=\mathrm{f} \text { (gearing levels }+ \text { tangibility }+ \text { size }+ \text { growth) }
$$

Where, $\mathrm{Y}=$ return on assets/return on equity 
$\mathrm{ROA} / \mathrm{ROE}=\mathrm{f}$ (gearing levels + tangibility + size + growth)

Gearing is the proportion of external finance used in financing the operations of the firm. This gearing may be calculated as follows;

1) Ratio of capital with fixed returns (CWFR) (preference share capital and long term liabilities) to the ratio of capital with variable return (CWVR) (share capital from ordinary shares). OR

2) CWFR: Capital employed (CE) OR

3) CWFR as a \% of capital employed.

Table 3. Description and measurement of variables

\begin{tabular}{llll}
\hline Variable y & Description & Measurement & Expected performance \\
\hline ROE & Return on equity & Ratio of Net income (KES)/total equity (KES) & Positive/Negative performance \\
ROA & Return on Assets & Ratio of Net profit (KES)/total assets (KES) & Positive/Negative performance \\
Gearing & Gearing levels & CWFR as a \% of Capital Employed & \\
Levels & & L.G $=>0-\langle 30 \%$ & Positive performance \\
& & MG1 $=30 \%-<35 \%$ & Positive performance \\
& & MG $2=\geq 35 \%-<40 \%$ & Negative performance \\
& & MG $3=\geq 40 \%-\leq 60 \%$ & Negative performance \\
Variable y & Description & Measurement & Negative performance \\
Tangibility & tangibility & Ratio of Fixed Assets (KES) to Total Assets (KES) & Pxpected performance \\
Size & Size of the firm & total assets(KES) & Positive performance \\
Growth & Growth of the firm & Change in net sales(KES) & Positive performance \\
\hline
\end{tabular}

This study used CWFR as a \% of capital employed method in deriving the gearing levels of the firms. With external finance in form of debt, comes tax deductibility, this was an added advantage of debt finance in form of savings in corporate taxes. Earnings were expected to be high possibly dividends would-be high. External finance however had costs. At some point of gearing level, the benefits of debt finance would be more than the cost of debt finance. Beyond this point which may be referred to as optimum level, the cost of debt finance may be more than the benefit of debt finance. Earnings would decline because the cost of capital (WACC) and the cost associated with risks of debt financing would be higher than the benefit of debt. Financial distress cost which include direct costs to bankruptcy and indirect bankruptcy costs (the costs of avoiding bankruptcy) could be more than the benefit of debt financing. This may affect the financial performance of firms and could lead to failure of firms.

Some other variables may determine a firm's financial performance (Ramaswammy, 2001; Frank \& Goyal, 2003; Jermias, 2008; Ebaid, 2009). These are;

1) Tangibility was derived as ratio of Fixed Assets to Total Assets (FA: TA). It was expected to be positive. The more fixed assets a firm had, the higher would be the production which in turn resulted in more sales and increase in earnings if demand was high.

2) The size was derived from the log of sales. It may also be natural logarithm of net assets. The size of the firm was expected to be positive. The bigger the size of the firm, the higher were the expected earnings and better performance of firms.

3) Growth was derived as change in net sales. It may also be derived as change in total assets. Overall growth of the firm was expected to be positive with an increase in sales resulting to an increase in earnings.

There are different measures for financial performance of firms. The measures include the accounting and market ratios. These are derived from the firm's financial statements (Majumdar \& Chlubber, 1999; Abor, 2005; Ebaid, 2009; Saed \& Mahmoodi, 2011).

This study used two common accounting ratios to evaluate the firm's financial performance; return on equity and return on assets. These were the dependent variables of the study. Financial Information for these variables was obtained from secondary data observed from the financial statement (the income statement and the balance sheet) for each firm from 2003 up to 2015.

The dependent variables measure of financial performance included;

1). ROE derived as annual net income divide by total equity. 
2). ROA derived as annual net profit after tax divide by total assets.

From the empirical model, the impact of capital structure gearing levels on financial performance in the 139 sampled firms was specified.

\section{Results and Discussion}

In this chapter, the results are presented and discussed. Section 4.1 presents descriptive analysis of sampled firms, section 4.2 presents the test of hypothesis and section 4.3 presents the empirical results.

\subsection{Sampled Firms: A Descriptive Analysis}

\subsubsection{Capital Structure of Sampled Firms}

Objective one of the study sought to assess the capital structures of public and private firms in the Kenya's Coastal Counties. Table 4 below presents the actual capital structure of the sampled firms while Table 5 presents the actual capital structure forms.

Table 4. General Capital Structures Forms of firms in the sample

\begin{tabular}{lll}
\hline Capital Structures Forms & No of firms & $\%$ \\
\hline Share capital. & 6 & 4.3 \\
Reserves -revenues and capital & 133 & 95.7 \\
Share capital & & \\
Reserves -revenues and capital Liabilities & & \\
-Preference share capital & & $100 \%$ \\
-Long term loan & 139 & \\
-Short term loans & & \\
Totals & & \\
\hline
\end{tabular}

Source: Field Survey, August 2018.

As the table above shows, all firms in the sample had capital structures of various forms. It was generally observed that $95.7 \%$ of firms used a capital structure composed of internal and external finance while only about $4.3 \%$ of firms used a capital structure composed of internal finance only.

Table 5. Actual capital structure forms of sampled firms

\begin{tabular}{|c|c|c|c|}
\hline Capital Structures Forms & No of firms' & Population (\%) & state of firm \\
\hline 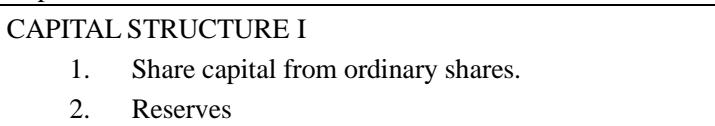 & 6 & 4.3 & $\begin{array}{l}\text { Unlisted at SE, mixed, } \\
\text { medium and large mature. } \\
\text { Some are public. }\end{array}$ \\
\hline $\begin{array}{ll}\text { CAPITAL STRUCTURE II } \\
\begin{aligned} \text { 1. } & \text { Share capital from ordinary shareholders } \\
\text { 2. } & \text { Revenue reserves. } \\
\text { 3. } & \text { Preference share capital ( Non-Controlling Interest) } \\
\text { 4. } & \text { Long term loan } \\
\text { 5. } & \text { Short term loan }\end{aligned}\end{array}$ & 2 & 1.4 & $\begin{array}{l}\text { Listed at SE, mature and } \\
\text { large. }\end{array}$ \\
\hline $\begin{array}{ll}\text { CAPITAL STRUCTURE III } \\
\begin{array}{ll}\text { 1. } & \text { Share capital from ordinary shareholders. } \\
\text { 2. } & \text { Reserves }\end{array}\end{array}$ & 14 & 10.1 & $\begin{array}{l}\text { Mixed, listed and unlisted at } \\
\text { SE mature large and some are } \\
\text { public. }\end{array}$ \\
\hline $\begin{array}{l}\text { 3. Long term loan } \\
\text { 4. Short term loan }\end{array}$ & No of firms & Population (\%) & State of firm \\
\hline Capital Structures Forms & & & \\
\hline 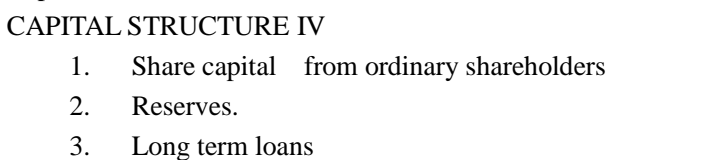 & 10 & 7.2 & $\begin{array}{l}\text { Mixed, listed and unlisted at } \\
\text { SE, mature large and some } \\
\text { are public. }\end{array}$ \\
\hline 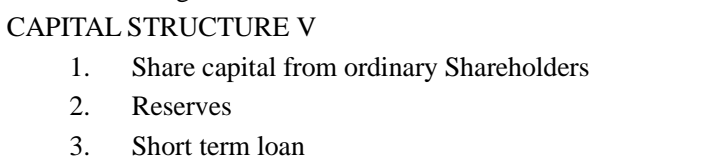 & 107 & 77 & $\begin{array}{l}\text { Unlisted at SE, all private, } \\
\text { mixed mature large and } \\
\text { medium. }\end{array}$ \\
\hline
\end{tabular}

Source: Field Survey, August 2018. 
Further, about $1.4 \%$ of firms in the sample used capital structure composed of internal finance and three options of external finance; preference share capital, long term loans and short term loans, $10.1 \%$ of the firms in the sample used capital structure composed of internal finance and two options of external finance; long term loans and short term loans, $7.2 \%$ of the firms in the sample used capital structure composed of internal finance and one option of external finance; long term loans while $77 \%$ of the firms in the sample used capital structure composed of internal finance and one option of external finance; short term loans. Majority of firms in Kenya`s coastal counties (77\% of the firms in the sample) therefore used capital structure whose external finance had only one option; short term finance. Despite the higher cost of short term finance and its shorter period of payment, the reason why most of these firms in the coastal counties use short term financing is that it has less stringent eligibility requirements making the approval process faster and also, it does not require a very strong financial history.

\subsubsection{Capital Structure Gearing Levels}

Objectives two of this study sought to assess the capital structure gearing levels of public and private firms in Kenya's Coastal Counties. Table 6 is an Extract which shows the various gearing levels and the proportion of firms in the sample which have those gearing levels.

Table 6. Gearing levels of sampled firms, 2018

\begin{tabular}{lcc}
\hline Gearing level & No. of firms & No. of firms in percentage \\
\hline 0 levels & 6 & 4.3 \\
$>0-<30 \%$ LG & 53 & 38.13 \\
$30 \%-<35 \%$ MG1 & 18 & 12.95 \\
$\geq 35 \%-<40 \%$ MG2 & 15 & 10.8 \\
$\geq 40 \%-\leq 60 \%$ MG3 & 30 & 21.6 \\
$>6$ O $\%$ HG & 17 & 12.2 \\
TOTAL & 139 & 100 \\
\hline
\end{tabular}

Source: Field Survey, August 2018.

The results shows that about $4.3 \%$ of the sampled firms did not gear their capital structure, these firms relied on internal resources. About $95.7 \%$ of the firms geared their capital structure. Out of these, $38.13 \%$ had low gearing, $12.95 \%$ had medium gearing one, $10.6 \%$ had medium gearing two, and $21.6 \%$ had medium gearing three while $12.2 \%$ had high gearing.

The gearing levels moved up and down in opposite direction with increases in reserve. Actual gearing moved up in tandem with needs of the firm and financing operations.

As the study shows, firms relied heavily on reserves, however between medium gearing one and high gearing, there was a population of $57.55 \%$ of firms. The single most popular gearing level was low gearing with a population of $38.13 \%$.This low gearing does not appear to be by design but rather it is because firms with this gearing levels are mature. Mature firms are those that are able to generate sufficient internal reserves which they use to finance their operations. This was followed by medium gearing three with a population of $21.6 \%$, medium gearing one with a population of $12.95 \%$, high gearing with a population of $12.2 \%$ and lastly medium gearing two with a population of $10.8 \%$ in that order.

The growth pattern of gearing level showed that gearing was an ongoing process. It evolved in response to needs of the firm. It moved up to meet the needs of the firm. Internal reserves however suppressed the upward movement though with no consistency.

\subsubsection{Gearing Levels and Financial Performance}

The third objectives of this study was to determine the effect of gearing levels on financial performance. This objective employed both descriptive and inferential statistics (regression analysis) as measured by return on equity and return on assets. Table 7 shows the general statistics of the sample while Table 8 shows the gearing level of firms, the proportion of firms with that gearing level and the financial performance at each gearing level. 
Table 7. General descriptive statistics of the sampled firms

\begin{tabular}{lcccc}
\hline Variable & Minimum & Maximum & Mean/Average & No. of firms \\
\hline ROE & $-1.35 \%$ & $51.5 \%$ & $22.9 \%$ & 139 \\
ROA & $-46 \%$ & $40.4 \%$ & $12.3 \%$ & 139 \\
$>0-<30 \%$ (LG) & $6 \%$ & $28.5 \%$ & $18.7 \%$ & 139 \\
$\geq 30 \%-<35 \%$ (MG1) & $30 \%$ & $34.4 \%$ & $32.0 \%$ & 139 \\
$\geq 35 \%-<40 \%$ (MG2) & $35 \%$ & $39.1 \%$ & $37.1 \%$ & 139 \\
$\geq 40 \%-\leq 60 \%$ (MG3) & $41.4 \%$ & $60 \%$ & $53 \%$ & 139 \\
Variable & Minimum & Maximum & Mean/Average & No. of firms \\
$>60 \%$ (HG) & $63.2 \%$ & $165 \%$ & $81.3 \%$ & 139 \\
Size & $4.27 \%$ & $7.96 \%$ & $5.89 \%$ & 139 \\
Tangibility & $27.1 \%$ & $75 \%$ & $66 \%$ & 139 \\
Growth & $-15 \%$ & $16 \%$ & $4 \%$ & 139 \\
\hline
\end{tabular}

Source: Field Survey, August 2018.

It is observed that the average return on equity of the sample of firms was $22.9 \%$, the lowest return on equity was $-1.35 \%$ while the highest return on equity was $51.5 \%$.On the other hand, the average return on assets was $12.3 \%$, the lowest return on assets was $-46 \%$ while the highest return on assets was $40.4 \%$.

At low gearing range, firms used reserves to finance their operations. This reduced gearing levels. The average gearing level was $18.7 \%$, the lowest gearing level was $6 \%$ while the highest gearing level was $28.5 \%$.At medium gearing one range, the average gearing level was $32.0 \%$, the lowest gearing level was $30 \%$ while the highest gearing level was $34.4 \%$.At medium gearing two range, the average gearing level was $37.1 \%$, the lowest gearing level was $35 \%$ while the highest gearing was $39.1 \%$. At medium gearing three range, the average gearing level was $53 \%$, the lowest gearing level $41.4 \%$ while the highest gearing level was $60 \%$.At high gearing range, the average gearing level was $81.3 \%$, and the lowest gearing level was $63.2 \%$ while the highest gearing level was $165 \%$.

With regard to size, the average size of firms was 5.89 , with the lowest size being 4.27 while the highest was 7.96. For tangibility, the average fixed assets to total assets was $66 \%$, the lowest fixed assets to total assets was $27.1 \%$ and the highest fixed assets to total assets was $75 \%$ while for growth, the general average growth was $4 \%$, the lowest was a fall of $-15 \%$ while the highest was a growth of $16 \%$.(Overall appendix 2 section $f$ shows positive growth for some firms and negative growth for other firms).

Table 8. Gearing levels and financial performance of firms sampled in Kenya's coastal counties.

\begin{tabular}{|c|c|c|c|c|c|c|c|c|c|c|c|c|c|c|c|c|c|}
\hline \multirow[b]{2}{*}{ Gearing levels } & \multicolumn{2}{|c|}{ FIRMS } & \multicolumn{3}{|l|}{ ROE } & \multicolumn{3}{|c|}{ ROA } & \multicolumn{3}{|l|}{ SIZE } & \multicolumn{3}{|c|}{ TANGIBILITY } & \multicolumn{3}{|c|}{ GROWTH } \\
\hline & No & $(\%)$ & Min & Max & $\mathrm{Av}$ & Min & Max & $\mathrm{Av}$ & Min & $\max$ & $\mathrm{Av}$ & $\min$ & $\max$ & $\mathrm{Av}$ & $\min$ & $\max$ & $\mathrm{Av}$ \\
\hline $0 \%$ & 6 & 4.32 & - & - & - & - & - & - & - & - & - & - & - & - & - & - & - \\
\hline$>0-<30 \%$ (LG) & 53 & 38.13 & 0.9 & 31.2 & 14.4 & 1.0 & 17.2 & 11.27 & 4.27 & 8.45 & 6.02 & 0.28 & 0.75 & 0.75 & 0.15 & 0.08 & 0.01 \\
\hline $30 \%-<35 \%(\mathrm{MG} 1)$ & 18 & 12 & 19.3 & 36.0 & 22.34 & 12.8 & 19.0 & & 3.45 & 6.47 & 5.44 & 0.33 & 0.75 & 0.64 & 0.08 & 0.16 & 0.03 \\
\hline$\geq 35 \%-<40 \%(\mathrm{MG} 2)$ & 15 & 10.79 & 15.6 & 34.4 & 25.47 & 12.3 & 20.4 & 15.0 & 5.0 & 7.51 & 5.89 & 0.27 & 0.75 & 0.55 & 0.04 & 0.10 & 0.03 \\
\hline$\geq 40 \%-\leq 60 \%(\mathrm{MG} 3)$ & 30 & 21.58 & 11.2 & 42.1 & 28 & 4.7 & 16.3 & 12.72 & 4.8 & 6.59 & 5.14 & 0.30 & 0.75 & 0.46 & -0.10 & 0.11 & 0.02 \\
\hline$>60 \%(\mathrm{HG})$ & 17 & 12.2 & -1.35 & 51.5 & 31.42 & -46 & 40.4 & 11.9 & 4.15 & 6.29 & 5.69 & 0.69 & 0.75 & 0.74 & -0.40 & 1.79 & 0.04 \\
\hline Total & 139 & $100 \%$ & & & & & & & & & & & & & & & \\
\hline
\end{tabular}

Source: Field Survey, August 2018.

Table 8 shows gearing levels of firms and financial performance of firms at each gearing levels. Based on these results, $4.32 \%$ of the firms are not geared, $38.13 \%$ are low geared, $12.95 \%$ are at medium gearing one level, $10.79 \%$ are at medium gearing two level, $21.58 \%$ are at medium gearing three level while $12.2 \%$ are at a high gearing level.

At low gearing, average return on equity was $14.4 \%$, the lowest return on equity was $0.9 \%$ while the highest return on equity was $31.2 \%$. The average return on assets was $11.27 \%$, the lowest return on assets was $1.0 \%$ while the highest was $17.2 \%$. This explains that at this level, firms are considered low risk, this is because the firms are mature and are able to generate sufficient internal reserves which they use to finance their operations.

At medium gearing one, the average return on equity was $22.34 \%$, the lowest return on equity was $19.3 \%$ while 
the highest return on equity was $36 \%$. The average return on assets was $15.29 \%$, the lowest return on assets was $12.8 \%$ while the highest return on assets was $19 \%$.The return on equity and return on assets as measured by the firms in this levels shows that these type of firms are well established since this gearing level is typically considered as the optimal level of gearing. The coefficient is highest, the benefits are maximized and the costs are minimum at this range.

At medium gearing two, the average return on equity was $25.47 \%$, the lowest return on equity was $15.6 \%$ while the highest return on equity was $34.4 \%$. The average return on assets was $15 \%$, the lowest return on assets was $12.3 \%$ while the highest return on assets was $20.4 \%$.The firms' performance as measured by the return on equity and the return on assets shows that at this gearing level costs have slightly began to rise as benefits begin to diminish.

At medium gearing three, the average return on equity was $28 \%$, the lowest return on equity was $11.2 \%$ while the highest return on equity was $42.1 \%$. The average return on assets was $12.72 \%$, the lowest return on assets was $4.7 \%$ while the highest return on assets was $16.3 \%$.The results clearly explains how firms at this gearing level may be at a financial risk because during times of lower profits and higher interest rate, the firms would be more susceptible to loan default and bankruptcy but to a lesser extent compared to the firms that are at a high gearing levels.

At high gearing, the average return on equity was $31.42 \%$, the lowest return on equity was $-1.35 \%$ which was the extreme negative return on equity while the highest return on equity was $51.5 \%$ which was the extreme positive return on equity. The average return on assets was $11.9 \%$, the lowest return on assets was $-46 \%$ which was the extreme negative return on assets while the highest return on assets was $40.4 \%$ which was an extreme positive return on assets. This explains that firms at this level would be at a greater financial risk, this is because these firms may be vulnerable to economic downturn since this gearing level works well during good economic times only. As clearly indicated from the study, at this gearing level, there was an extreme positive return on equity of $51.5 \%$ and an extreme negative return on equity of $-1.35 \%$. There was also an extreme positive return on assets of $40.4 \%$ and an extreme negative return on assets of $-46 \%$. Firms reported the lowest return on equity of $-1.35 \%$ and the lowest return on assets of $-46 \%$.

Size, tangibility and growth are also determinants of the financial performance of a firm, in this study, they are treated as control variables.

In regard to size, at low gearing, medium gearing one, medium gearing two, medium gearing three and high gearing levels, average size was $6.02 \%, 5.44 \%, 5.89 \%, 5.14 \%$, and $5.69 \%$ respectively while the smallest size was $4.27 \%, 3.45 \%, 5.0 \%, 4.8 \%$ and $4.15 \%$ respectively. The biggest size was $8.45 \%, 6.47 \%, 7.51 \%, 6.59 \%$ and $6.29 \%$ respectively. From this data, the maximum size of the firm was at low gearing level with $8.45 \%$, this is because firms at this gearing level are able to generate sufficient internal reserves which they use to finance their operations, this was followed by firms in the medium gearing two level, medium gearing three level, followed by medium gearing one and lastly high gearing level.

In regard to tangibility, at low gearing, medium gearing one, medium gearing two, medium gearing three and high gearing the average fixed assets to total assets was $0.75 \%, 0.64 \%, 0.55 \%, 0.46 \%$ and $0.74 \%$ respectively while the lowest fixed assets to total assets was $0.28 \%, 0.33 \%, 0.27 \%, 0.30 \%$ and $0.69 \%$ respectively, this explains that low geared firms have a lower ratio of fixed assets to total assets compared to high geared firms. The highest was $0.75 \%$ for all, this explains that the firms fixed assets to total assets was $0.75 \%$ at all gearing levels

In regard to growth, at low gearing, medium gearing one, medium gearing two, medium gearing three and high gearing levels, average growth was $0.01 \%, 0.03 \%, 0.03 \%, 0.02 \%$ and $0.04 \%$ respectively while the lowest growth was $0.15 \%, 0.08 \%, 0.04 \%, 0.11 \%$ and $-0.40 \%$ respectively. The highest growth was $0.08 \%, 0.16 \%$, and $0.10 \%, 0.11 \%$ and $1.79 \%$ respectively, this explains that highly geared firms have the highest opportunity of growth compared to low geared firms.

Both positive and negative growth were observed in firms in the sample. This is suggested by the reason that some firms were operating in growth or stable environment while others were operating in unstable (dynamic) environment. This finding was also reflected in financial performance of firms in the sample where both positive and negative return on equity and return on assets were observed.

There were firms with low gearing and without the benefit of internal reserves, these firms had low investments in fixed assets and therefore were smaller in size. There were other firms with high gearing and without the benefit of internal reserves, these firms had high investments in fixed assets and were bigger in size. There were 
also firms with low gearing but with the benefit of high internal reserves, they had high investments in fixed assets and were bigger in size. Other firms also had high gearing and with the benefit of high internal reserves, they had high investments in fixed assets and were bigger in size.

\subsection{Test of Hypothesis}

Regression was conducted to establish the impact of gearing on financial performance of firms. Hypothesis which were tested were;

\section{Hypothesis 1}

Ho: there was no significant effect of low gearing on financial performance of firms.

\section{Hypothesis 2}

Ho: there was no significant effect of medium gearing one on financial performance of firms.

\section{Hypothesis 3}

Ho: there was no significant effect of medium gearing two on financial performance of firms.

Hypothesis 4

Ho: there was no significant effect of medium gearing thereon financial performance of firms.

Hypothesis 5

Ho: there was no significant effect of between high gearing on financial performance of firms.

From Table 8 above, the hypothesis are rejected. In both stable and unstable environment, the gearing levels (low gearing, medium gearing one, medium gearing two, medium gearing three and high gearing) had positive effect on financial performance of firms.

\subsection{Empirical Results and Discussion}

Table 9 shows results for regression of models using low gearing, medium gearing one, medium gearing two, medium gearing three and high gearing on return on equity and return on assets.

\subsubsection{Regression Analysis}

The table below shows the results for the regression model using low gearing, medium gearing one, medium gearing two, medium gearing three and high gearing on return on equity and return on assets

Table 9. Regression model using LG, MG1, MG2, MG3 and HG

\begin{tabular}{|c|c|c|c|c|c|c|c|c|c|c|}
\hline & \multicolumn{2}{|c|}{$\begin{array}{l}>0-<30 \% \\
(\text { LG) }\end{array}$} & \multicolumn{2}{|c|}{$\begin{array}{l}30 \%-\langle 35 \% \\
\text { (MG1) }\end{array}$} & \multirow{2}{*}{$\begin{array}{l}\mathbf{3 5 \%} \\
\text { (MG2) } \\
\text { ROE } \\
\end{array}$} & \multirow{2}{*}{$\begin{array}{l}-\quad \mathbf{4 0} \% \\
\text { ROA } \\
\end{array}$} & \multirow{2}{*}{$\begin{array}{l}\geq 40 \% \\
\text { (MG3) } \\
\text { ROE } \\
\end{array}$} & \multirow{2}{*}{$\begin{array}{l}-\leq 60 \% \\
\text { ROA }\end{array}$} & \multirow{2}{*}{$\begin{array}{c}>60 \% \\
(\mathrm{HG}) \\
\mathrm{ROE}\end{array}$} & \multirow[b]{2}{*}{ ROA } \\
\hline & ROE & ROA & ROE & ROA & & & & & & \\
\hline Constant & 6.057 & 16.968 & 8.686 & 5.163 & 23.75 & 14.639 & 2.21 & 12.22 & 3.547 & 0.683 \\
\hline Gearing & 0.589 & 0.702 & 1.121 & 0.786 & 0.810 & 0.612 & 0.532 & 0.118 & 0.714 & 0.166 \\
\hline Tangibility & 1.762 & -10.257 & -5.78 & 1.266 & -14.25 & -1.617 & 1.528 & 5.57 & 75.25 & 99.19 \\
\hline Size & -0.50 & 0.397 & 3.629 & 0.983 & 1.13 & 0.115 & 0.509 & -0.705 & 4.65 & 12.625 \\
\hline Growth & 76.11 & -34.52 & -32.89 & 0.199 & 77.02 & 24.07 & 2.898 & 22.59 & 11.05 & 1.370 \\
\hline Adjusted $\mathrm{R}^{2}$ & 0.337 & 0.164 & 0.249 & 0.239 & 0.236 & 0.159 & 0.140 & 0.121 & 0.269 & 0.64 \\
\hline Observations & 1717 & 1717 & 1717 & 1717 & 1717 & 1717 & 1717 & 1717 & 1717 & 1717 \\
\hline
\end{tabular}

Source: Field Survey, August 2018.

Table 9 presents results of the relationship between the gearing levels 0 - $<30 \%$ (LG), $30 \%-<35 \%$ (MG1), $\geq 35 \%$ $-<40 \%$ (MG2), $\geq 40 \%-\leq 60 \%$ (MG3), $>60 \%(\mathrm{HG})$, tangibility, size and growth and the firm's financial performance. The results indicate that all independent variables have strong effect on firm's financial performance as measured by ROE and ROA which are the dependent variables. ROE and ROA are low at less than 30\%gearing level because of the lack of financial advantages of gearing. The ratios are highest at between $30 \%$ and less than $35 \%$ because the benefits of gearing are greater than the costs of gearing and the associated risks. At gearing levels of above $35 \%$, the costs and risks associated with gearing are greater than the benefits.

The regression coefficient of low gearing level for return on equity and return on assets are 0.589 and 0.702 respectively. This means that if low gearing changes by 0.1 it would increase return on equity and return on assets by 0.589 and 0.702 respectively, assuming all other factors remain the same. The hypothesis 1 is therefore 
rejected as low gearing has positive effect on the two measurement; return on equity and return on assets in the study. As a result, a proportion of low gearing in the capital structure would lead to higher return on equity and return on assets. The coefficient of fixed assets to total assets are 1.762 and -10.257 for return on equity and return on assets respectively. This indicates that if fixed assets to total assets changes by 0.1 return on equity and return on assets will move by 1.762 and -10.257 respectively. Overall fixed assets to total assets has positive effect on return on equity and negative effect on return on assets in this study. Size and growth have negative relation to return on equity and return on assets respectively. The coefficients of size is -0.50 for return on equity and 0.397 for return on assets. The coefficient for growth is 76.11 for return on equity and -34.52 for return on assets. The adjusted $\mathrm{R}^{2}$ show that in the model for return on equity gearing explains $33.7 \%$ of all variability of return on equity and $16.4 \%$ for return on assets.

For the model using medium gearing one, the result shows that medium gearing one has positive impact on the return on equity and return on assets measures. The coefficients of medium gearing one for return on equity and return on assets are 1.121 and 0.786 respectively. This indicates that if medium gearing one increase by 0.1 , it will increase return on equity and return on assets by 1.121 and 0.786 respectively if other conditions are constant. The hypothesis 2 is rejected as medium gearing one leads to higher return on assets and return on equity for firms. Fixed assets to total assets has negative effect on return on equity and positive effect on return on assets. The coefficient of fixed assets to total assets is -5.78 and 1.266 for return on equity and return on assets respectively. The size and growth have negative and positive relation to return on equity and return on assets respectively. The coefficients of size is 3.629 for return on equity and 0.983 for return on assets. The coefficient for growth is -32.89 for return on equity and 0.199 for return on assets. The adjusted $\mathrm{R}^{2}$ show that in the model for return on equity gearing explains $24.9 \%$ of all variability of return on equity and $23.9 \%$ for return on assets.

The result for the model using medium gearing two shows that it has positive effect on the return on equity and return on assets measures .The coefficients of medium gearing two for return on equity and return on assets are 0.810 and 0.612 respectively. This indicates that if medium gearing two increase by 0.1 , it will increase return on equity by 0.810 and return on assets by and 0.612 respectively if other conditions are constant. The hypothesis 3 is rejected as medium gearing two leads to higher return on assets and return on equity for firms. Fixed assets to total assets has negative effect on return on equity and on return on assets. The coefficient of fixed assets to total assets is -14.83 and -1.617 for return on equity and return on assets respectively. The size and growth have positive relation to return on equity and return on assets respectively. The coefficients of size is 1.13 for return on equity and 0.115 for return on assets, the coefficient for growth is 77.02 for return on equity and 24.05 for return on assets. The adjusted $\mathrm{R}^{2}$ show that in the model for return on equity gearing explains $23.6 \%$ of all variability of return on equity and $15.9 \%$ for return on assets

The result for the model using medium gearing three shows that it has positive effect on the return on equity and return on assets measures. The coefficients of medium gearing therefore return on equity and return on assets are 0.532 and 0.118 respectively. This indicates that if medium gearing three increase by 0.1 , it will increase return on equity by 0.532 and return on assets by 0.118 respectively if other conditions hold. The hypothesis 4 is rejected as medium gearing three leads to higher return on assets and return on equity for firms. Fixed assets to total assets has positive effect on return on equity and return on assets. The coefficient of fixed assets to total assets is 1.528 and 5.57 for return on equity and return on assets respectively. The size and growth have positive and negative relation to return on equity and return on assets respectively .The coefficients of size is 0.509 for return on equity and -0.705 for return on assets, the coefficient for growth is 2.898 for return on equity and 22.59 for return on assets. The adjusted $\mathrm{R}^{2}$ show that in the model for return on equity, gearing explains $14.0 \%$ of all variability of return on equity and $12.1 \%$ for return on assets

The result for the model using high gearing shows that it has positive effect on the return on equity and return on assets measures.The coefficients of high gearing for return on equity and return on assets are 0.714 and 0.166 respectively. This indicates that if high gearing increases by 0.1 , it will increase return on equity by 0.714 and return on assets by 0.166 respectively if other conditions hold. The hypothesis 5 is rejected as high gearing leads to higher return on assets and return on equity for firms. Fixed assets to total assets has positive effect on return on equity and return on assets. The coefficient of fixed assets to total assets is 75.25 and 99.19 for return on equity and return on assets respectively. The size and growth have positive relation to return on equity and return on assets respectively. The coefficients of size is 4.65 for return on equity and 12.625 for return on assets, the coefficient for growth is 11.05 for return on equity and 1.370 for return on assets.

The coefficients of low gearing, medium gearing one, medium gearing two, medium gearing three and high gearing are significant. They are significant at $5 \%$ for low gearing, $3 \%$ for medium gearing one, $6 \%$ for medium 
gearing two, $7 \%$ for medium gearing three and $10 \%$ for high gearing.

On the adjusted $\mathrm{R}^{2}$ (see Table 9 ) gearing levels can explain variability of both return on equity and return on assets. For return on equity, gearing can explain variability at between $14 \%$ and $33.7 \%$ and for return on assets gearing can explain variability at between $12.1 \%$ and $64.1 \%$. This means between $66.3 \%$ and $86 \%$ variability of return on equity are explained by other factors while between $35.9 \%$ and $87.9 \%$ variability of return on assets are explained by other factors.

The observations (1717) is obtained by taking the number of sample firms (139 firms) multiplied by the number of years under observation (2003 to 2015) and the 0.95 confidence level.

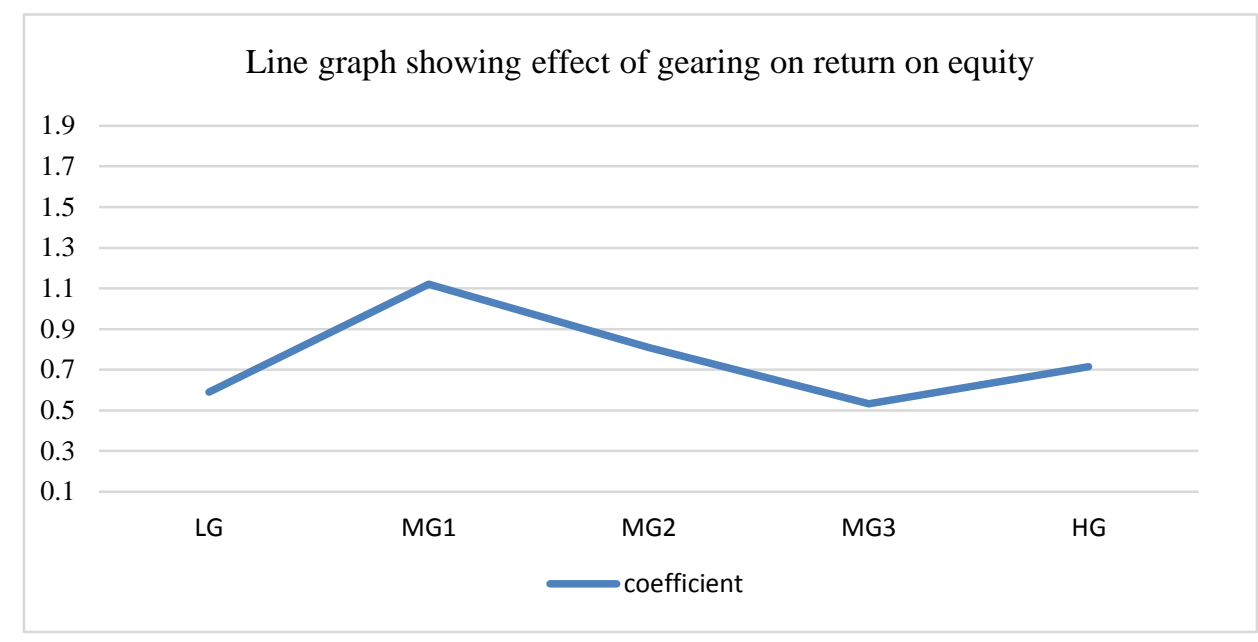

Figure 4. Line graph showing effect of gearing on return on equity

Source: Field survey, August 2018.

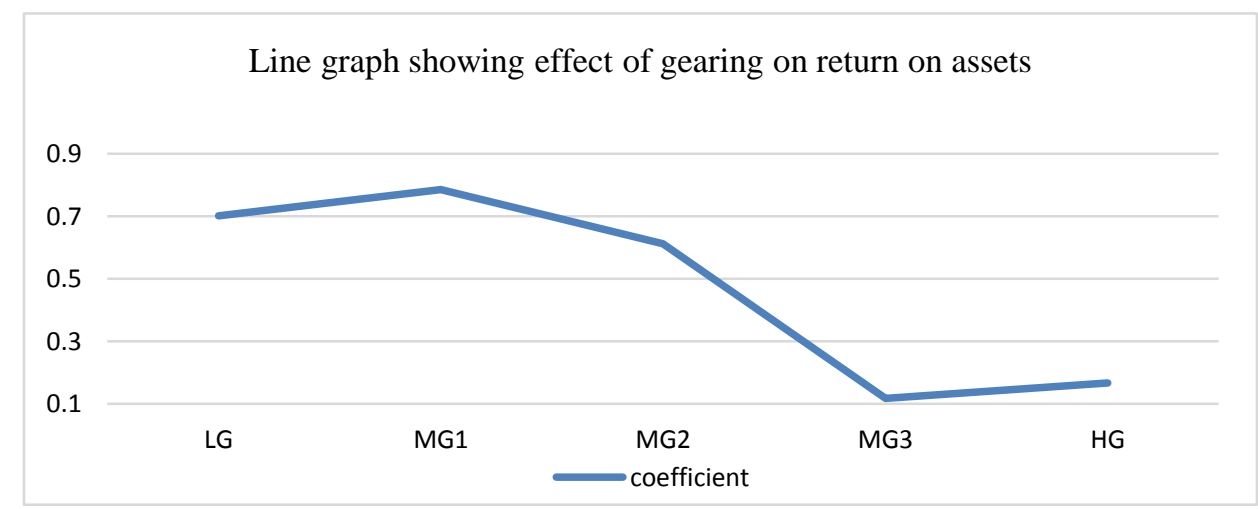

Figure 5. Line graph showing effect of gearing on return on assets

Source: Field survey, August 2018.

From Table 9, the coefficients $0.589,1.121,0.810,0.532$ and 0.714 are for low gearing, medium gearing one, medium gearing two, medium gearing three and high gearing respectively for return on equity. There is a rise from low gearing up to the optimum level at medium gearing one before a decline is observed at medium gearing two and gearings that follow. The coefficients $0.702,0.786,0.612,0.118$ and 0.166 are for low gearing, medium gearing one, medium gearing two, medium gearing three and high gearing respectively for return on assets. As in the case of return on equity, there is a similar pattern where there is lower coefficient at low gearing and a peak at medium gearing one before a decline is observed at medium gearing two and gearings that follow.

The results of this study are similar to previous studies. These include a study by Githire (2015) on the effects of capital structure on financial performance of firms listed at NSE in Kenya which concluded that equity and short term debt financing enhanced financial performance while short term debt reduced financial performance. 
An investigation by Hassan et al. (2013) on the influence of capital structure on firms performance on 36 Bangladesh firms listed in Dhaka stock exchange concluded that capital structure had negative impact on firms performance.

A study conducted by Mahfuzah et al. (2012) on the effects of capital structure on firms financial performance on 237 Malaysian listed companies found that firm's performance measured by return on assets, return on equity and earnings per share had negative relationship with short term debt, long term debt and total debt as independent variables, they concluded that total debt has significant negative relationship with the performance of the firm.

A study of the capital structure and firms performance in Vietnam that examined the impact of capital structure on firms performance in selected 147 firms listed on HCMC stock exchange found a negative impact of level of leverage on firm's performance (Tristan et al., 2015).

Harwood's (2015) study of effects of debt on firm's performance on commercial banks listed in Nairobi securities exchange found that debt negatively affected firm's performance though not statistically significant as measured by return on assets.

According to Siyambola (2015), the results of the investigation on the impact of gearing on financial performance of companies of Nigeria revealed that efficiently managed gearing could lead to increase in earnings of the company. In the finding, gearing had direct relationship with the performance of the company and that gearing provided some advantages with positive impact on profitability.

Tianyu's (2013) study on the influence of capital structure on firm's performance in both developed and developing markets documented that capital structure had a negative effect on firm's performance in China and significant positive effect in two European Countries, i.e. Germany and Sweden, before financial crisis in 2008. A sample of 1200 listed firms in Germany and Sweden and 1000 listed firms in China for the period 2003-2012 had been used in this study.

A study on effects of capital structure on firm's performance on manufacturing companies in Nigeria found that capital structure, total debt and debt to equity ratio were negatively related to firm performance and recommended that firms use more equity than debt in financing their business activities in as much as the value of the business can be enhanced using debt capital (Lawal et al., 2014).

Ibrahim's (2009) study on the influence of capital structure choice on firm performance in Egypt concluded that firm performance had weak to no relationship with capital structure choice. Likewise, Khalaf (2013) also found negative and insignificant relationship between short term and long term debt ratio and return on assets and profit margin.

Some studies that were conducted were in conflict with the findings in this study; first, a study conducted by Margaritis and Psillaki (2010) observed a positive relation between leverage and firms performance, they found that leverage have positive effect on firms efficiency over the entire sample.

Second, using panel data consisting of 257 South African firms over the period 1998 to 2009, Samuel (2013) found a positive and significant relation between financial leverage and firm's performance.

Aliakbar et al. (2013) also found a significant positive link between Capital Structure and firm performance in the Tehran Stock Exchange.

However, some authors got mixed results. In this, Kinsman and Newman (1998) found that earnings are negatively correlated with short-term debt, but are positive with long term debt in US corporations. A similar result was found by Mesquita and Lara (2003) in Brazil.

In this study on the effect of Capital Structure gearing levels on financial performance of public and private sector firms in Kenya's Coastal Counties, the study shows that low gearing, medium gearing one, medium gearing two and medium gearing three have a positive effect on the financial performance of the firms in both stable and unstable environment while high gearing has positive effect on financial performance in a stable environment and negative financial performance in an unstable environment.

\section{Summary, Conclusions and Recommendations}

This chapter presents the summary, conclusions and policy recommendations of the study.

\subsection{Summary}

The study was conducted in order to determine the effect of capital structure gearing levels on financial performance of firms in the Kenya's coastal counties and whether this contributed to poor financial performance. 
Majority of firms in Kenya's coastal counties (77\% of the firms in the sample) used capital structure whose external finance had only one option; short term finance. The results shows that capital structure gearing levels of public and private firms in Kenya's Coastal Counties where the growth pattern of gearing level was an ongoing process evolved in response to needs of the firm.

In the determination of the effect of gearing levels on financial performance of firms as measured by return on equity and return on assets, the hypotheses were that the gearing levels (low gearing, medium gearing one, medium gearing two, medium gearing three and high gearing) had no effect on financial performance of firms and was rejected. Low gearing had positive effect on the financial performance as measured by return on equity and return on assets. Medium gearing one increased return on equity and return on assets, medium gearing two and medium gearing three leads to higher return on assets and return on equity for firms. High gearing leads to higher return on assets and return on equity for firms in a stable environment and low returns in an unstable environment. Fixed assets to total assets has positive effect on return on equity and return on assets. $57.55 \%$ of firms had gearing levels of over 30\%. Without set target gearing levels the firms were likely to borrow more thereby falling into debt trap. The gearing may result in financial distress costs and more gearing may lead to higher distress costs. At gearing level of $>0 \%$ and $\measuredangle 35 \%$, the financial distress costs are lower while at $>35 \%$, the financial distress costs are higher. Higher gearing levels and associated costs were the cause of poor financial performance and failure of firms in the Kenya`s Coastal Counties.

In regard to gearing levels and financial performance of firms, low gearing, medium gearing one, medium gearing two, medium gearing three and high gearing have effect on financial performance of firms. In both stable and unstable environment, low gearing, medium gearing one, medium gearing two and medium gearing three had positive effect on financial performance of firms. Low gearing, medium gearing one, medium gearing two and medium gearing three had positive effect on financial performance of firms in both stable and unstable environment. High gearing however had both positive and negative effect on financial performance of firms. In a stable environment, high gearing had positive effect on financial performance of firms while in unstable environment high gearing had negative effect on financial performance of firms. In comparison high gearing had the highest positive effect on financial performance of firms than medium gearing three, medium gearing two, medium gearing one and low gearing in that order. In a stable environment, based on average return on equity, the gearing levels with the highest positive effect on financial performance of firms was high gearing, medium gearing three, medium gearing two, medium gearing one and low gearing in descending order. The best capital structure therefore is one which is high on debt (high gearing).In an unstable environment however, based on average return on equity, the gearing level with the lowest return on equity was high gearing followed by medium gearing three, medium gearing two, medium gearing one and low gearing in that order. Under stable conditions the higher the gearing therefore, the higher the expected earnings and vice versa.

Based on coefficients of gearing for return on equity and for return on assets, the higher the gearing the higher the expected return but at a diminishing rate. Returns are low at low gearing but are at peak at medium gearing one before a decline is observed at medium gearing two, medium gearing three and high gearing. Possibly, therefore the optimum level of gearing may be at medium gearing one level as coefficient is highest. The market shared price may be maximized at this range at minimum cost. Beyond this point, costs begin to rise as benefits begin to diminish.

\subsection{Conclusion}

In the assessment of the capital structure of public and private sector firms in the Kenya's coastal counties, the majority of firms in Kenya's coastal counties used capital structure composed of short term debt finance, the costs could be higher and thereby affecting financial performance of firms as capital structure with short-term debt financing and its accompanying costs add to cost of business and also threaten solvency of firms. Unlike short term debt, long term debt financing has some financial benefits. Interest rates are normally lower because these loans are usually secured with collateral like property and this makes its cost of borrowing lower than unsecured short term loans which have higher rates. This suggests that capital structure composed of short term debt financing and higher costs of debt financing was the cause of poor financial performance and failure / insolvency of firms in Kenya's Coastal Counties.

The assessment of the capital structure gearing levels of the public and private sector firms in the Kenya's coastal counties leads to the conclusion that firms in Kenya's coastal counties had affinity for gearing and more affinity for higher gearing levels of over $30 \%$. The growth pattern of gearing level of firms suggests that gearing was an ongoing process and that it evolved in response to needs of the firm. It moved up to meet the needs of the firm. Internal reserves however suppress the upward movement but with no consistency. This suggests that firms 
did not have set target capital structure gearing level.

The determination of the effect of the capital structure gearing levels on financial performance of public and private sector firms in the Kenya's coastal counties leads to the conclusion that in a stable environment, there was a steady growth in net income. In such an environment high gearing (HG) had higher positive effect on financial performance of firms than medium gearing levels three (MG3), medium gearing level two (MG2), medium gearing level one (MG1) and low gearing (LG). Return on equity was higher at high gearing level where under this environment, the best capital gearing level would be high capital gearing level. In an unstable environment however, net income growth fluctuates violently. In this environment high gearing had negative effect on financial performance of firms. Return on equity was lowest for firm with highest gearing than medium gearing three (MG3), medium gearing two (MG2), medium gearing one (MG1) and low gearing (LG). Return on earnings was highest for the firm with low gearing in this environment. This leads to the overall conclusion that gearing has positive and negative effects on firm's financial performance. In a stable economic environment, the best capital structure is one which is high on debt as return on equity is highest. This is the objective of owners of firms which is wealth maximization. Therefore, under stable economic environment, high gearing leads to positive financial performance of firms. In an unstable economic environment however, the worst capital structure gearing level is one which is highly geared (HG), It leads to negative financial performance of firms.

With regard to tangibility, measured by fixed assets to total assets, it has been found to be both positive and negative in most results. This indicates that some firms in Kenya Coastal Counties have invested in fixed assets while some did not invest adequately in fixed assets. Some firms were able to take advantages of the fixed assets and use them effectively than others. As a result financial performances was affected.

Size was positively related to return on equity and return on assets of firms in Kenya's Coastal Counties. Firms with higher fixed assets to total assets made use of assets to increase sales, consequently net income. Some firms with higher fixed assets to total assets made use of assets through better management and more investments to enjoy the advantages of economies of scale and financial slack.

Growth was positively related to return on equity and return on assets of firms in Kenya's coastal counties. Higher growth minimized overall Weighted Average Cost of Capital (WACC) such that with more sales, there was more net income from use of the same assets leading to better financial performances of firms.

\subsection{Recommendations}

Several recommendations emanate from this study. Firstly, the firms should use a capital structure which has a higher component of long term finance because long term finance has a lower interest cost compared to short term finance and the probability of incurring financial distress cost leading to insolvency will be minimal.

Secondly, managers should gear their firms to an optimum level of up to less than $35 \%$.At this level, the financial distress costs and associated risks are equal to the benefits. Beyond the optimum level, the financial distress costs and associated risks will begin to exceed the benefits and this may lead to insolvency and failure of the firms.

Thirdly, the environment under which firms operate is unstable. There will be systematic and unsystematic risks which will have effect of financial performance. Higher levels of gearing have a higher effect on financial performance of firms compared to lower gearing levels. The researcher therefore recommends that managers should avoid higher gearing levels for better financial performance of their firms.

Finally, firms should have programs of investment in fixed assets to grow the tangibility ratio (fixed assets to total assets) and also the growth of the firm. They should also invest in marketing strategies such as advertisements to grow their sales and improve on the growth of the firm.

\subsection{Further Research}

That gearing levels are able to explain part variation of financial performance, the other part variation of financial performance are explained by other factors. Research should be conducted to establish other elements which affect financial performance of firms in Kenya`s Coastal Counties and /or Kenya as a whole. The study also recommends that empirical research be conducted to establish the optimum capital structure gearing level for firms in Kenya's Coastal Counties and in Kenya as a whole to provide a guide to finance managers, to determine the effect of gearing levels on financial performance of firms by sectors. Another study may be conducted to determine the effects of the benefits of special purpose enterprise on financial performances of the partnered firms in the U.K in order to justify its adoption for use in Kenya. 


\section{Acknowledgements}

I am greatly indebted to my supervisors; Prof. Samuel M. Mwakubo and Dr. Ali Ibrahim Abdallah for their guidance, contribution and commitment to the provision of education in general and in the realization of this project.

I also appreciate the commitment and support of the Pwani university fraternity for their contribution and for making this a success.

\section{References}

Abor, J. (2005). The effect of capital structure on profitability: An empirical analysis of listed firms in Ghana. Journal of Risk Finance, 6(5), 438-447. https://doi.org/10.1108/15265940510633505

Aliakbar, R., Seyed, H. S. N., \& Pejman, M. (2013). The relationship between capital structure decisions with firm performance. World of Sciences Journal, 1(9), 83-89.

Allen, N. (2002). Capital structure and firms performance in US banking industry.

Al-Taani, K. (2013). The relationship between capital structure and firm performance. Journal of Finance and Accounting, 1(3), 41-45. https://doi.org/10.11648/j.jfa.20130103.11

Anup, C., \& Suman, P. (2010). The impact of capital structure on firm's value in Bangladesh.

Arowoshegbe, A. O., \& Idialu, J. O. (2013). Capital structure and profitability of quoted companies in Nigeria. International Journal of Business and Social Research, 3(3), 99-106.

Baker, M., \& Wurgler, J. (2002). Market timing and capital structure. Journal of Finance, 57(1), 1-32. https://doi.org/10.1111/1540-6261.00414

Bierman, H., \& Hausman, W. H. (1970). The credit Granting decision. Management Science, 16, B519-B532. https://doi.org/10.1287/mnsc.16.8.B519

Bokhtiar et al. (2013). Influence of capital structure on firm performance-evidence from Bangladesh.

Brealey, \& Myers. (1991). Principles of Corporate finance.

Brealey, R. A. (1991). Principles of Corporate finance. McGraw House.

Champion, D. (1999). Finance: The joy of leverage. Harvard Business Review, 77(4), 19-22.

Ebaid, I. E. S. (2009). The impact of capital structure choice on firm performance: Empirical evidence from Egypt. Journal of Ridk Finance, 10(5), 477-487. https://doi.org/10.1111/0022-1082.00320

Ebrati, R. M., Farzad, E., Reza, S. B., \& Ghorban, S. (2013). The impact of capital structure on firm performance: Evidence from Tehran Stock Exchange. Australian Journal of Basic \& Applied Sciences, 7(4), 1-8.

Ezra, S. (1969). The theory of financial management.

Githire, C., \& Muruti, W. (2015). Effects of capital structure on financial performance of firms in Kenya: Evidence from firms listed at the NSE.

Gleason, C., Lynette, K., \& Ike, M. (2000). The relationship between capital structure and performance.

Harwood, I. K. (2015). The effect of debt on firms' performance on commercial banks listed in NSE.

Jensen, M. C., \& Meckling, W. H. (1976). Theory of the firm: Managerial behavior, agency costs and ownership structure. Journal of Financial Economics, 3(4), 305-360. https://doi.org/10.1016/0304-405X(76)90026-X

Kenduiwo, E. K. (2014). The relationship between alternative sources of finance and Financial performance of small and medium enterprises in Nairobi County.

Kenya treasury department, statement 2015.

Kinsman, D., \& Newsman, A. (1998). The relationship between debt level and firms performance.

Lavorskyi M. (2013). The impact of capital structure on firm performance in Ukraine.

Lawal, A. (2014). The effects of capital structure on firms performance on manufacturing companies in Nigeria.

Madiavale, E. M. (2016). Effect of lean practices on operational performance of Microfinance institutions in Mombasa County.

Mahfuzah, S., \& Raj, Y. (2012). Capital structure and firms performance on Malaysian listed companies.

Manawaduge, A., Zoysa, A. D., Chowdhury, K., \& Chandarakumara, A. (2011). Capital structure and firm 
performance in emerging economies: An empirical analysis of Sri Lankan firms. Corporate Ownership \& Control, 8(4), 253-263. https://doi.org/10.22495/cocv8i4c2art2

Margaritis, D., \& Psillaki, M. (2010). Capital structure; equity ownership and firm performance. Journal of Banking \& Finance, 34(3), 621-632. https://doi.org/10.1016/j.jbankfin.2009.08.023

Markowitz, H. M. (1959). Portfolio selection: efficient diversification of investments. New Yolk; Wiley.

Mesquita, J. M. C., \& Lara, J. E. (2003). Capital Structure and Profitability: The Brazilian case. Academy of Business and Administration Sciences Conference, Vancouver.

Miller, M. H. (1991). Financial innovations and market volatility. Blackwell, Cambridge, MA, and Oxford UK.

Modigliani, F., \& Miller, M. H. (1958). The cost of capital, corporation finance, and the theory of investment. America's Economic Review, 48(3), 261-297.

Modigliani, F., \& Miller, M. H. (1963). Corporate income taxes and the cost of capital: A correction. American Economic Review, 53(3), 443-453.

Mohamad, N. E. A. B., \& Abdullah, F. N. B. A. (2012). Reviewing relationship between capital structure and firm's performance in Malaysia. International Journal of Advances in Management and Economics, 1(4), 151-156.

Moyer, R. C. (1984). Contemporary Financial Management. West Publishing Company.

Mumtaz, R., Rauf, S. A., Bashir, A., \& Noreen, U. (2013). Capital structure and financial performance: Evidence from Pakistan (Kse 100 Index). Journal of Basic and Applied Scientific Research, 3(4), 113-119.

Muriithi, S. N. (2014). The effect of financing sources on the financial performance of top 100 mid-sized companies in Kenya.

Myers, S. C., \& Majluf, N. S. (1984). Corporate financing and investment decisions when firms have information that investors do not have. Journal of Financial Economics, 13(2), 187-221. https://doi.org/10.1016/0304-405X(84)90023-0

Niajini A., Priya K.B. (2013), the impact of capital structure on financial performance of listed trading companies in Sri Lanka.

Nor, E., \& Fatihah. (2012). The impact of debt and equity financing on the performance of the firms in Malaysia.

Pandey, I. M. (2011). Financial management. Vikas, Publishing House.

Phillips, P., \& Sipahioglu, M. (2004). Performance implications of capital structure: Evidence from quoted UK organizations with hotel interest. The Service Industries Journal, 24(5), 31-51. https://doi.org/10.1080/0264206042000276829

Popescu, L., \& Visinescu, S. (2009). Economic science, a review of capital structure theories.

Quyen, T. K. N., \& Alan, M. R. (2014). Internal equity financing and the Performance of multinational subsidiaries in emerging economies.

Rajan, R. G., \& Zingales, L. (1995). What do we know about capital structure? Some evidence from international data. Journal of Finance, 50(5), 1421-1460. https://doi.org/10.1111/j.1540-6261.1995.tb05184.x

Reynor, C. A. O. (2013). Strategies for asset financing to enhance performance of Commercial banks in Kenya.

Roden, D., \& Lewellen, W. (1995). Capital structure and firms performance.

Saeedi, A., \& Mahmoodi, 1. (2011). Capital Structure and firm performance: Evidence from Iranian companies. International Research Journal of Finance and Economics, 70, 20-29.

Salim, M., \& Yadev, R. (2012). Capital structure and firm performance: Evidence from Malaysian listed companies. Social and Behavioral Sciences, 65, 156-166. https://doi.org/10.1016/j.sbspro.2012.11.105

Salteh, H. M., Ghanavati, E., Khanqah, V. T., \& Khosroshahi, M. A. (2012). Capital structure and firm performance; Evidence from Tehran Stock Exchange. International Proceedings of Economics Development \& Research, 43, 225-230.

Siyambola, T. T. (2015). The impact of gearing on performance of firms in Nigeria.

Solomon, E., \& Pringel. (1978). An introduction tofinancial management. London Prentice Hall.

Suleiman, A. (2013). Capital structure effect on firms' performance: Evidence from Saudi listed companies. 
Saint Mary's University, Master's thesis. Retrieved from http://library2.smu.ca/bitstream/lhandle/01/25264/alawwad_suleiman_mrp_2013.pdf?sequence-1

Tianyu, H. (2013). The comparison of impact from capital structure to corporate performance between Chinese and European listed firms. Master's thesis of Jonkoping University. Retrieved from http://urn.kb.se/resolve?Urn=urn.nbn.se.hj.diva-21994

Tristan, N., \& Huy-Cuong, N. (2015). Capital structure and firms performance in Vietnam.

Umar, M., Tanveer, Z., Aslam, S., \& Sajid, M. (2012). Impact of capital structure on firms' financial performance: Evidence from Pakistan. Research Journal of Finance and Accounting, 3(9), 1-12.

Van Home, J., \& Wachowiez, 1. (1995). Fundamentals of financial management (9th ed.). New Jersey: Prentice Hall.

Weston, \& Brigham. (1979). Essentials of managerial finance.

World Bank report. 2010.

Zeitun, R., \& Tian, G. G. (2007). Capital structure and corporate performance: Evidence from Jordan. The Australasian Accounting Business and Finance Journal, 1(4), 40-61.

\section{Copyrights}

Copyright for this article is retained by the author(s), with first publication rights granted to the journal.

This is an open-access article distributed under the terms and conditions of the Creative Commons Attribution license (http://creativecommons.org/licenses/by/4.0/). 